Research, part of a Special Feature on Programme on Ecosystem Change and Society (PECS): Knowledge for Sustainable Stewardship of Social-ecological Systems

\title{
Scale and ecosystem services: how do observation, management, and analysis shift with scale_-lessons from Québec
}

\author{
Ciara Raudsepp-Hearne ${ }^{1}$ and Garry D. Peterson ${ }^{2}$
}

\begin{abstract}
Ecosystem service assessment and management are shaped by the scale at which they are conducted; however, there has been little systematic investigation of the scales associated with ecosystem service processes, such as production, benefit distribution, and management. We examined how social-ecological spatial scale impacts ecosystem service assessment by comparing how ecosystem service distribution, trade-offs, and bundles shift across spatial scales. We used a case study in Québec, Canada, to analyze the scales of production, consumption, and management of 12 ecosystem services and to analyze how interactions among 7 of these ecosystem services change across 3 scales of observation $\left(1,9\right.$, and $75 \mathrm{~km}^{2}$ ). We found that ecosystem service patterns and interactions were relatively robust across scales of observation; however, we identified 4 different types of scale mismatches among ecosystem service production, consumption, and management. Based on this analysis, we have proposed 4 aspects of scale that ecosystem service assessments should consider.
\end{abstract}

Key Words: covariance; ecosystem service bundles; Mont Saint-Hilaire; problem of fit; scaling; social-ecological; spatial; trade-offs

\section{INTRODUCTION}

The management of ecosystem services requires scaleappropriate information about the condition, dynamics, and use of multiple, and often interacting, ecosystem services. However, choosing the scale at which ecosystem services should be assessed is not evident. The issue of scale is complex in ecosystem service research and assessment because individual and bundles of ecosystem services are generated by a variety of social-ecological processes and structures, each with distinct spatial scales. The distribution of benefits and the management of ecosystem services also occur at particular scales. Interactions between some ecosystem services may be observable at some scales and not others, and information generated at particular scales may or may not be usable by managers acting at other scales.

Managers need to know at what scales ecosystem services are produced, used, or accessed to identify associated societal values and management incentives. Understanding the scales of these different processes is important in developing an effective management approach that takes into account the presence or absence of social-ecological feedbacks (Reyers et al. 2013). Ecosystem services are being assessed at many different spatial scales (Malinga et al. 2015), but how scale matters for ecosystem service assessment is poorly understood. Despite recognition of the importance of scale in ecosystem service research (MA 2003), very little is known about the scales associated with different ecosystem service processes, and there are few tools or approaches for making sense of scale in ecosystem service assessment and management (MA 2003, de Groot et al. 2010). Some researchers have suggested that information should be developed at the social scales where decision making occurs (Gitay et al. 2005), but decision making often occurs at multiple scales and may require more complex multiscale assessments (Scholes et al. 2013).

To produce clear and relevant information about ecosystem services, research and assessments must consider the scales of different ecosystem service processes and be aware of the implications of choosing a particular scale of observation and analysis. We address these issues by first introducing what we hypothesize to be important scale issues related to the assessment of ecosystem service processes in social-ecological systems. Second, we explore these issues in a case study system in southern Québec, Canada (Raudsepp-Hearne et al. 2010). To analyze how scale of observation affects the information that is gathered about interactions among ecosystem services, we quantify and map seven ecosystem services at three spatial scales and an additional five services at the largest scale. We also compare the characteristic scales of ecosystem service processes, i.e., production, benefit distribution, and management, to investigate management implications of whether they are aligned with each other. Finally, we propose four aspects of scale that ecosystem service assessments should consider.

Scale of ecosystem service processes versus scale of observation Ecosystem services are produced by social-ecological systems that are managed and shaped by humans (Andersson et al. 2007, Reyers et al. 2013). Management and engineering to enhance some ecosystem services can lead to both positive and negative impacts on other ecosystem services (Bennett et al. 2009). An ecosystem service "bundle" is the set of ecosystem services that is produced in a particular area as a result of engineering, management, and ecosystem service interactions, and it represents the net ecosystem service benefits that are available to the population living there (Raudsepp-Hearne et al. 2010).

Ecosystem service patterns observed in assessments are influenced by the characteristic scales of the underlying processes and the scale of observation (Hein et al. 2006). For example, water quality is produced at the scale of a watershed (Cumming et al. 2006); however, a local manager might monitor water quality at a smaller scale. The scale of observation determines the relative fineness or coarseness of details and patterns that are observed 
in a system and therefore included in an analysis, which can have major implications for how a system is understood and managed (Lant et al. 2005, Martín-López et al. 2009).

\section{Scales of production, consumption, and management of} ecosystem services

Ecosystem services are produced by land uses and their geographic patterns, ecological structures and functions, biodiversity, management practices, and complex interactions between ecological and social dynamics (Fisher et al. 2009, Reyers et al. 2013, Bennett et al. 2015). Determining the scale of ecosystem service production thus entails identifying the scale of all system components that contribute to ecosystem service production (Fisher et al. 2009).

The consumption of ecosystem service benefits occurs at multiple scales. By consumption, we mean the distribution of benefits associated with ecosystem services, which can be consumed, made use of, or simply enjoyed. We use the term "consumption" as shorthand to capture multiple uses and enjoyment of nature's benefits, including both material and nonmaterial benefits. For example, farmers are the primary beneficiaries of crop production from which they gain their livelihoods, but the crops may also benefit people who sell or eat them or enjoy associated cultural practices. Understanding the scale of consumption is key to managing ecosystem services effectively, for example by developing scale-appropriate management incentives. The identification of scales of consumption also allows the identification of potential conflicts in environmental management, in particular between local stakeholders and stakeholders at other scales. Access to ecosystem services is moderated by how land and natural resources are managed (see next paragraph) and has scale-related repercussions for consumption patterns (Reyers et al. 2013).

Societies manage ecosystem services using rules and actions to alter the production or access to ecosystem services. We distinguish landscape engineering and controlling access to ecosystem services as two important types of ecosystem service management, each of which is associated with management rules and actions. Ecosystem service management may be nonexistent, e.g., for many regulating ecosystem services; may occur directly at the level of the site, e.g., a farmer or urban family altering ground cover; or may occur at larger scales, e.g., provincial or national laws regulating harvests or pollution (Chapin et al. 2006). Identifying the scale at which ecosystem services are managed is an important part of deciding on the scale of ecosystem service assessment because assessing ecosystem services at scales of institutions facilitates the uptake of information generated (Lant et al. 2005). However, management institutions may not always exist at the most appropriate scale (Turner and Daily 2008).

\section{Scale mismatches}

The scales of production, consumption, and management of ecosystem services do not necessarily align. Scale mismatches occur when the scale of environmental variation and the scale of the social organization responsible for use or management of ecosystem services are not aligned, causing a lack of feedback between social and ecological processes and potential inefficiencies, conflicts, or oversights in ecosystem service management (Cumming et al. 2006, 2013). The production of ecosystem services may not match the scales at which individuals or institutions manage ecosystem services, or the scale at which people benefit from the services.

There are several types of scale mismatches that could cause management problems. Management issues can arise when the scale of ecosystem service production is the same, greater than, or less than the scale of consumption, or when trade-offs among ecosystem services occur across scales (Fig. 1). When the scales of ecosystem service production and consumption do not match, the result may be a lack of management incentives or inadequate signals for ecosystem service management. Knowing more about the scales at which multiple, interacting ecosystem services are produced and consumed could help managers to avoid these situations.

\section{Scales of observation in ecosystem service assessment}

Observing the pattern of an ecosystem service on a map is helpful for developing effective and efficient management strategies for that service. When the processes described in the previous section are included in an ecosystem service assessment, the patterns they exhibit may vary depending on the scale of observation of the assessment. For example, previous work has found many ecosystem services to be highly clustered on landscapes, as opposed to evenly distributed, suggesting that observed patterns of ecosystem services will change significantly from one scale to the next (Turner and Daily 2008).

Additionally, single-scale observation may capture, miss, or distort ecosystem service interactions. Identifying trade-offs that exist among ecosystem services at different scales has been identified as critical to the sustainable management of ecosystem services (Carpenter et al. 2009, Bennett et al. 2015). For example, enhancing food production services at one site may produce tradeoffs with water quality at larger scales that will only be observed if the assessment incorporates those scales.

There is little systematic knowledge about how ecosystem services interact and how these interactions vary across scales. Few studies have analyzed multiple ecosystem services across a landscape, and still fewer have examined how their covariance changes across scales (however, see Holland et al. 2011). We can identify ecosystem service interactions when multiple ecosystem services are correlated across space, either positively or negatively (Chan et al. 2006, Egoh et al. 2008, Holland et al. 2011), or through the identification of ecosystem service bundles (Raudsepp-Hearne et al. 2010, Turner et al. 2014, Queiroz et al. 2015, Yang et al. 2015). Interactions can arise from the following: a biophysical connection between services, such as when phosphorus accumulation in soils leads to loss of water quality in nearby rivers or lakes; because of social compatibilities or incompatibilities, for example the isolation of concentrated pork production from tourism and recreation areas; or through shared impacts from different drivers of change, such as when reduced seasonal rainfall impacts crop production, animal habitat, and water quality (Bennett et al. 2009, Reyers et al. 2013).

We analyze three aspects of ecosystem service distributions that are relevant to their assessment and management and that may vary with the scale of observation (Fig. 2). These include (1) individual ecosystem service patterns, (2) pairwise ecosystem service interactions, and (3) ecosystem service bundles. 
Fig. 1. Management implications of different scale relationships between ecosystem service production and benefit distribution (adapted from Fisher et al. 2009).

SCALE MISMATCH

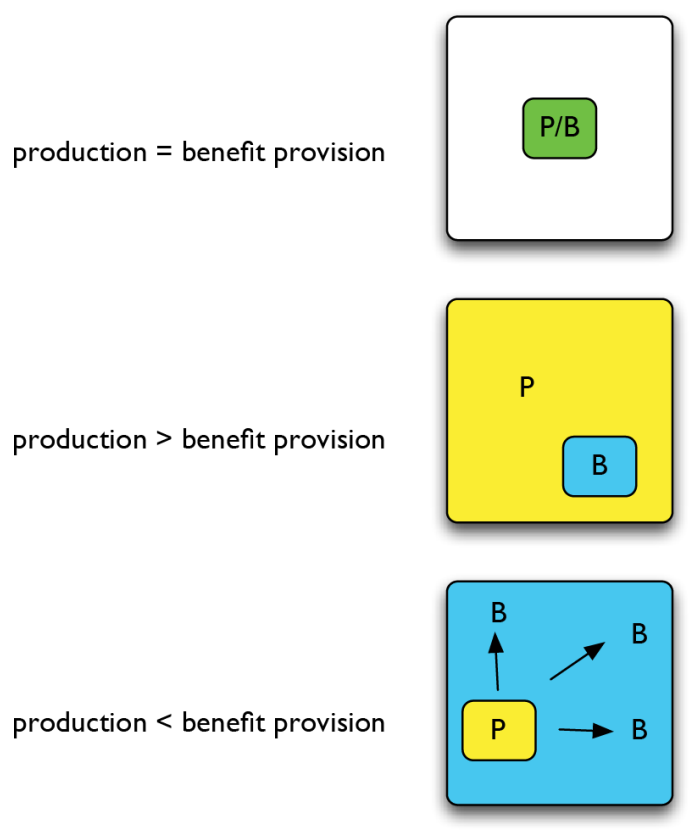

MANAGEMENT IMPLICATIONS

-Incentives aligned if beneficiaries are also managers

-Feedback from production directly to beneficiaries/managers

-Potentially insular, should check whether management interacts

with ecosystem services produced at other scales

-Potential for "tragedy of the commons"

-High potential for conflict

-Need for cooperation and management across scales

-Potential need for education about ecosystem service production

-May require cross-scale management in interactions with other

ecosystem services

-Incentives for management not in place

-Potential for using payment for ecosystem services to connect

producers and beneficaries

-May require cross-scale management in interactions with other ecosystem services
Fig. 2. Ecosystem service patterns and interactions can be substantially different depending on the scale at which these phenomena are observed.

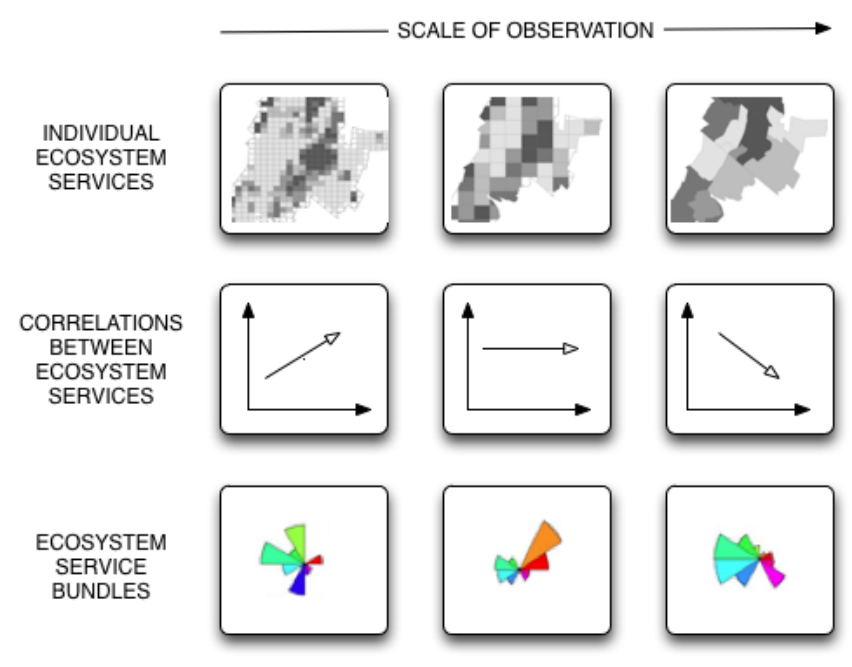

\section{METHODS}

Study site

The study site is centered on the Mont Saint-Hilaire United Nations Educational, Scientific, and Cultural Organization Man and Biosphere Reserve (MABR), which covers 15 municipalities in southern Québec $\left(\sim 700 \mathrm{~km}^{2}\right)$. These 15 municipalities are embedded within a larger study site consisting of 2 adjacent watersheds (Richelieu and Yamaska watersheds) that cover 137 municipalities ( $7288 \mathrm{~km}^{2}$; Fig. 3). The area surrounding Mont Saint-Hilaire is primarily agricultural ( $\sim 60 \%$ of land), with pockets of urban settlements ( $20 \%$ of land) and green spaces ( $16 \%$ of land; Cumming et al. 2006). Information on ecosystem services from the larger study area is included in the scale analyses of ecosystem services, but we focus on management implications for the MABR. The MABR differs from the larger study site in that it is closer to an urban area, includes an important protected area, and does not include large tracts of forested, hilly land that are found at the far east of the larger study area.

This region is typical of many peri-urban agricultural landscapes around the world with increasingly industrialized farms and growth in residential development and tourism (Statistics Canada 2004). Ecosystem services that are important in the region include those associated with agricultural practices, urban and peri-urban living, tourism, and recreation. A selection of ecosystem services that are most relevant to the people living within this system was chosen to include in our analysis (see Raudsepp-Hearne et al. 2010), also attempting to capture a roughly equal number of ecosystem services from provisioning, cultural, and regulating categories (Table 1).

\section{Ecosystem service quantification at multiple scales}

In the 15 municipalities of the Mont Saint-Hilaire MABR, we quantified 7 ecosystem services at 3 spatial scales (Table 1). The scales compared include $1 \mathrm{~km}^{2}(\mathrm{n}=587), 9 \mathrm{~km}^{2}(\mathrm{n}=81)$, and municipalities $\left(74 \mathrm{~km}^{2}, \mathrm{n}=15\right)$. We refer to the $1-\mathrm{km}^{2}$ spatial scale as the "smallest" spatial scale and the municipal spatial scale 
Table 1. Ecosystem services included in multiscale analyses. The ecosystem services that were quantified at all three spatial scales are marked with an asterisk; additional services were only quantified at the municipal scale.

\begin{tabular}{|c|c|c|c|c|}
\hline Category & Ecosystem Service & Unit & Data Source & Reference \\
\hline \multirow[t]{4}{*}{ Provisioning } & Crops* & $\%$ Land in crop & 2001 Census of Agriculture & $\begin{array}{l}\text { BDTQ (2005), Statistics Canada } \\
(2001 a)\end{array}$ \\
\hline & Pork* & Pigs $/ \mathrm{km}^{2}$ & 2001 Census of Agriculture & Statistics Canada (2001c) \\
\hline & Maple syrup* & Taps $/ \mathrm{km}^{2}$ & 2001 Census of Agriculture & Statistics Canada (2001b) \\
\hline & Drinking water & $\begin{array}{l}\text { Québec water quality } \\
\text { indicator (IQBP) (1-5) }\end{array}$ & Provincial water database & $\operatorname{MDDEP}(2008)$ \\
\hline \multirow{5}{*}{ Cultural } & Deer hunting* & Deer kills $/ \mathrm{km}^{2}$ & Private hunting company & SoftMap (2001) \\
\hline & Tourism* & Tourist attractions $/ \mathrm{km}^{2}$ & Provincial tourism database & MTQ $(2007 a, b)$ \\
\hline & Nature appreciation* & $\begin{array}{l}\text { Observations of rare species/ } \\
\mathrm{km}^{2}\end{array}$ & Provincial conservation database & CDPNQ (2007) \\
\hline & Forest recreation* & $\%$ Land that is forested & Provincial land-use database & BDTQ (2005) \\
\hline & Summer cottages & Tax value of cottages $/ \mathrm{km}^{2}$ & $\begin{array}{l}\text { Provincial tax database, municipal } \\
\text { data }\end{array}$ & MAMR (2007) \\
\hline \multirow[t]{3}{*}{ Regulating } & Carbon sequestration & In $\mathrm{kg} \mathrm{C} / \mathrm{km}^{2}$ & $\begin{array}{l}\text { Remote-sensing data (MODIS), } \\
2001 \text { Census of Agriculture }\end{array}$ & $\begin{array}{l}\text { LPDAAC (2001), } \\
\text { Statistics Canada (2001b) }\end{array}$ \\
\hline & Soil phosphorus retention & $\%$ & Provincial soil database & MAPAQ (2001) \\
\hline & Soil organic matter & $\%$ & Provincial soil database & MAPAQ (2001) \\
\hline
\end{tabular}

as the "largest" spatial scale. The smallest scale was chosen to represent the field or site scale, where individual management of the land is occurring. The middle scale was chosen to approximate a neighborhood or local landscape. The municipal scale was included because it is the scale at which many formal landscape management decisions are made. Very small scales, e.g., variation within a site, were not included, because these scales require resource-intensive fieldwork to sample and thus are not generally included in landscape-scale assessments. In the remaining 122 municipalities within the Richelieu and Yamaska watersheds, data were unavailable at the smaller scales, but 12 ecosystem services were quantified at the municipal scale. This allowed us to qualitatively analyze more types of ecosystem services in terms of their production, consumption, and management.

Fig. 3. Map of Man and Biosphere Reserve (MABR) within larger case study area. Mont Saint-Hilaire MABR (15 municipalities) is shaded dark gray within the larger study area of the Richelieu and Yamaska watersheds.

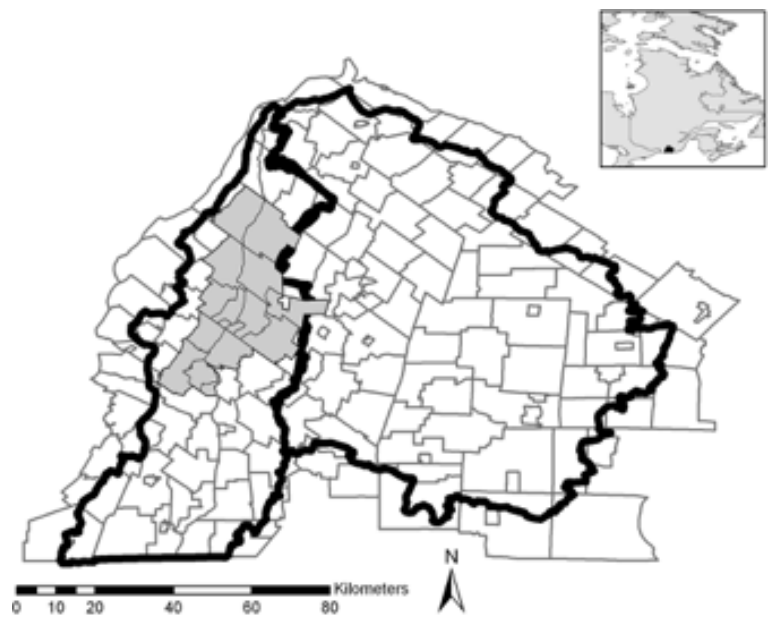

Detailed methods on how each ecosystem service was quantified at each scale are found in Appendix 1. We constructed grids in ArcGIS to sample data at the 2 smaller spatial scales. At the $1 \times$ $1 \mathrm{~km}$ scale, we included only grid cells that were completely within the boundaries of the study area, whereas at the $3 \times 3 \mathrm{~km}$ scale, grid cells with at least $50 \%$ of their area within the boundaries of the study area were included, and ecosystem service values were adjusted for area. At the largest (municipal) scale, we calculated the area of each municipality using boundaries from the 2001 Canadian census. A value for each service was calculated for each municipality and normalized for area. Ecosystem services at all scales were quantified using data for 2001 or as close as possible to this date. All data were transformed so that the maximum value of each ecosystem service in the landscape was set at 1 . Final data were imported into an ArcGIS database for data analysis.

\section{Analysis}

Scales of ecosystem service production, consumption, and management

We assessed the scales associated with the production, consumption, and management of the 12 ecosystem services using hierarchies of scale (Wu 1999). We assigned the production, consumption, and management of each ecosystem service to the following hierarchical categories: site, e.g., field to farm (approximately $<1 \mathrm{~km}^{2}$ ); local, e.g., neighborhood to municipality $\left(>1 \mathrm{~km}^{2}\right.$ to $\left.100 \mathrm{~km}^{2}\right)$; regional, e.g., tourism region or watershed $\left(>100 \mathrm{~km}^{2}\right.$ to $\left.1000 \mathrm{~km}^{2}\right)$; and global.

We identified scales of production by considering all the system components known to contribute to the production of that service, i.e., the ecosystem service production unit (as per Fisher et al. 2009). Evidence for ecosystem service production scales came from scientific literature and local sources of information on infrastructure and management (evidence is presented in Appendix 2).

We identified the scale of consumption for primary and secondary beneficiaries of each ecosystem service based on personal 
communications with local people and published information about the system. For example, farmers indicated that phosphorus retention in soil benefited them individually at the field scale and benefited people more generally at the landscape scale through protection of water quality (justification for each assignment is presented in Appendix 3).

To identify the scale of management of each service, we identified the managers in the region who both directly engineer the landscape to manage ecosystem services and regulate access to ecosystem services. For each of these categories we listed managers according to whether they performed actions directly on the landscape or whether they developed rules or policies. We identified the scale of management for each ecosystem service based on information from municipal and provincial government reports and websites (the principal managers in the region and examples of management actions and policies are presented in Appendix 4). Finally, we compared the scales of all of the previously mentioned processes, looking for scale alignment or mismatches.

Spatial patterns of ecosystem services across scales

We mapped individual ecosystem services in ArcGIS at the three spatial scales to visualize and compare their spatial patterns. We calculated spatial autocorrelation of ecosystem services at each scale using Moran's I with queen contiguity using the R statistical software package sp (Moran 1950, Bivand et al. 2013, R Core Team 2014).

Ecosystem service trade-offs, synergies, and bundles across scales To identify potential trade-offs and synergies among ecosystem services, we performed a correlation analysis among all 12 ecosystem services at the largest spatial scale (municipalities) and among all 7 ecosystem services at the smaller spatial scales $(3 \times$ $3 \mathrm{~km}$ and $1 \times 1 \mathrm{~km}$ grids). At the largest scale, correlation analysis was performed with all municipalities in the larger study region $(n=137)$. Correlation analyses were conducted using the Pearson parametric correlation test in $\mathrm{R}$. We then compared the number, direction, and strength of correlations among the 7 ecosystem services at each spatial scale to identify differences in service interactions across scales. Correlations among the additional 5 ecosystem services were analyzed only at the largest scale.

We identified distinct types of ecosystem service bundles at each scale using k-means clustering. We used three clusters, rather than the six found across the larger region (Raudsepp-Hearne et al. 2010) because of the lower number of ecosystem services and the reduced landscape diversity in the focal region. We compared the patterns between the three bundles detected at each scale. We also compared the bundles detected at the municipal scale to those found in an analysis of a larger landscape and a more diverse set of ecosystem services (Raudsepp-Hearne et al. 2010). The former comparisons indicate how the bundles change with scale, whereas the later analysis shows how the bundles vary with the ecosystem services that are included or the number of municipalities analyzed. Figures were created using the R packages maptools (Bivand and Lewin-Koh 2013) and RColorBrewer (Neuwirth 2011), and cluster analysis was conducted using the packages vegan (Oksanen et al. 2013) and fpc (Hennig 2013).

\section{RESULTS}

\section{Scales of ecosystem service production, consumption, and management}

Most of the ecosystem services in our study are produced either at the scale of a site or at the local scale. The exceptions are drinking water quality, which is produced at the scale of a watershed, and nature appreciation and deer hunting, which both rely on larger landscapes at the regional scale for species viability. Appendix 5 synthesizes all the results from the assignation of scales of production, benefit distribution, and management.

Most ecosystem service beneficiaries in the study area are consuming benefits at the site or local scales. "Local benefits" generally signifies the scale of the neighborhood landscape up to the scale of the municipality. Two regulating ecosystem services, soil retention of phosphorus and soil organic matter, benefit people primarily on-site, in other words on farmers' fields. However, soil retention of phosphorus also benefits people at the watershed level through the contribution of this service to maintenance of water quality. The third regulating service, carbon sequestration, is unique in our study as the only ecosystem service that benefits people at the global scale. Consumption or demand for most services extends to the regional scale.

All but three ecosystem services are managed directly through landscape engineering. Deer hunting, nature appreciation, and carbon sequestration, as they are defined and measured by us, are the only ecosystem services that are not enhanced purposefully through engineering at any scale. Although carbon sequestration is also not managed through rules or policies, or actions regulating access to the service, some management of these types is occurring for deer hunting and nature appreciation. For example, access to deer hunting is managed at the site scale through private property protection and at the regional scale through government policies and laws that prescribe licensing rules, quotas, and hunting seasons. Access to nature appreciation is managed through the building and maintenance of trails and by provincial laws that regulate conversion of protected areas. Several ecosystem services are not subject to rules regulating either landscape engineering or access. In particular, carbon sequestration and soil organic matter are not managed formally through any regulations, although soil organic matter is managed at the site level through landscape engineering.

Individuals and municipalities jointly manage the rest of the ecosystem services through actions and rules related to landscape engineering and access to services, with input from local and regional governing bodies and nongovernmental organizations (NGOs). For example, forest recreation is engineered through underbrush clearing at the site scale, and through trail building and maintenance by nature NGOs at the local scale. Municipalities, the regional government, and NGOs develop policies on what types of engineering are allowed in protected forests. Landowners limit access to private forests at the site scale, and the municipal and regional governments regulate access to protected forests through policy and law.

All engineering actions to enhance ecosystem services occur at the site scale and sometimes also at the local scale, in the cases of drinking water, tourism, and forest recreation. Actions regulating 
Fig. 4. Comparing scales of ecosystem service production, benefit distribution, and management, both engineering and access. (A) Scale of production versus scale of consumption. (B) Scale of production versus scale of management, landscape engineering. (C) Scale of production versus scale of management, access to services.
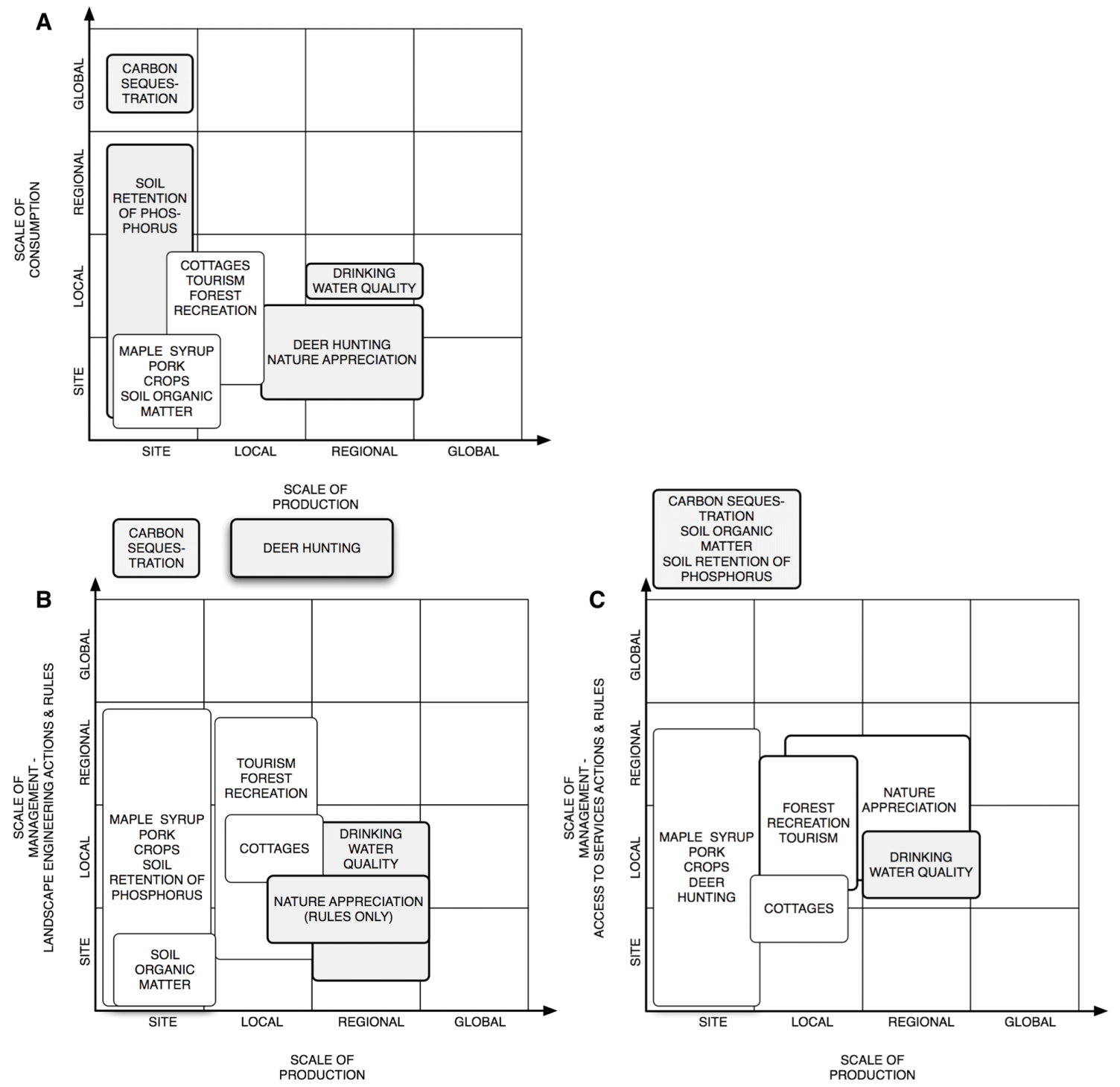

access to ecosystem services generally occur at site and local scales, and at the regional scale in the case of tourism, where governments promote tourism to enhance access to this service. Rules and regulations governing landscape engineering and access to services exist at both local and regional scales, according to government jurisdictions. NGOs can alter landscapes directly, for example by cleaning shorelines, but mostly try to influence how ecosystem services are managed at municipal and regional levels.

\section{Comparing scales of ecosystem service processes}

Several ecosystem services are produced, consumed, and managed at the same scale and could be called scale aligned, e.g., soil organic matter (see Fig. 4). In other cases, there are potential scale mismatches, where ecosystem services are produced at one scale, but the benefits accrue to people at a different scale, e.g., carbon sequestration. Figure 5 presents a summary of comparisons of ecosystem service production, consumption, and management, as well as ecosystem service interactions across scales.

\section{Spatial patterns of ecosystem services across scales}

All ecosystem services were significantly clustered in space at all scales, as opposed to uniformly distributed on the landscape ( $\mathrm{P}$ $<0.01)$, except for tourism at the municipal scale and pork at the intermediate scale $(\mathrm{P}>0.05)$. Ecosystem service patterns showed some trends in spatial clustering across scales. Four out of 7 
ecosystem services, i.e., crops, pork, maple syrup, and forest recreation, became less clustered when moving from observations at the smallest to the intermediate scale but were most clustered at the largest scale. Deer hunting became steadily more clustered on the landscape as the scale of observation increased. In contrast, tourism became less clustered as the scale of observation increased and was randomly dispersed at the largest scale. Only nature appreciation was most clustered at the intermediate scale.

Fig. 5. Summary of comparisons between scales of ecosystem service production, benefit distribution, and management, as well as the identification of instances of ecosystem service interactions that might pose scale issues for management.

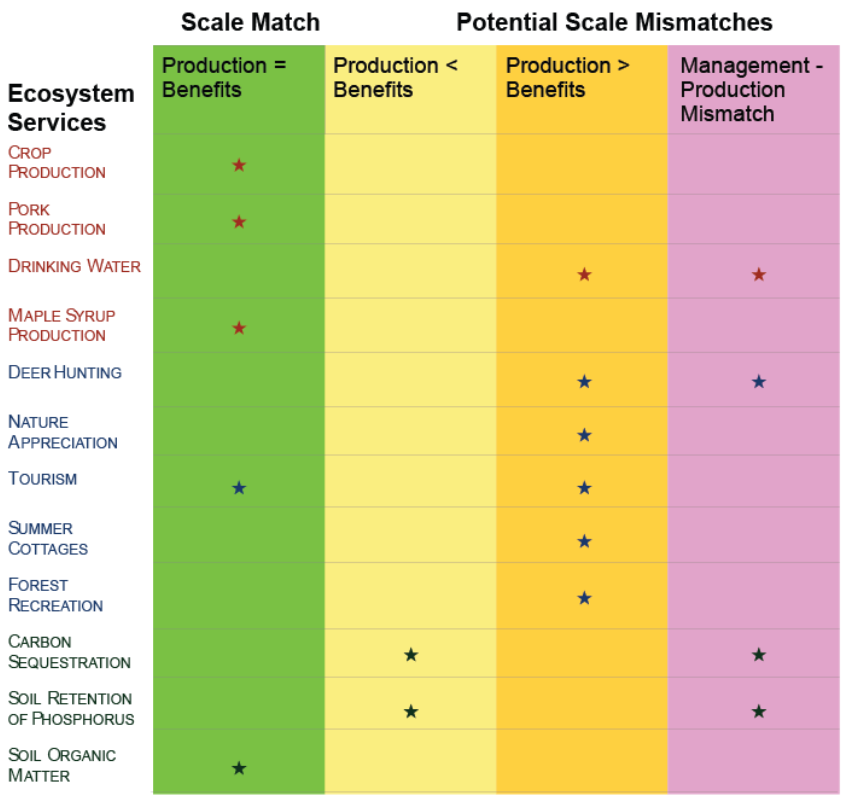

Ecosystem service patterns changed in visibly different ways as they were mapped across the three scales (Fig. 6). Crop production and forest recreation changed evenly across scales, and the extreme clustering of other ecosystem services was even more obvious on maps than it appeared through the spatial autocorrelation analyses. Pork production occupied only a few cells on the landscape at the smallest scale of observation, but this high degree of clustering was smoothed out at larger scales. The scaling behavior of other services, such as deer hunting and nature appreciation, was between these extremes. From most even distribution to least were crop production, forest recreation, deer hunting, maple syrup production, nature appreciation, tourism, and pork production.

Ecosystem service trade-offs, synergies, and bundles across scales Correlation analysis of 7 ecosystem services across 3 scales revealed similar patterns of positive and negative correlations at all scales (Fig. 7A, B, Appendix 6). However, there were more pairwise correlations among the 7 services at the 2 smaller scales than at the largest scale: 15 significant correlations at the 2 smaller scales versus 10 significant correlations at the largest scale $(\mathrm{P}<$ 0.05). Although 5 correlations were observed at both smaller scales that were not observed at the largest scale (Fig. 7C), the only interaction that was detected at the largest scale and not at smaller scales was the trade-off between pork production and nature appreciation.

At all scales, crop production was negatively correlated with all other services except pork production, significantly in all cases but 1 . Crop and pork production were positively correlated at all scales $(\mathrm{P}<0.05)$. Four correlations became steadily stronger as the scale of observation increased (Fig. 7A), whereas in all other cases the strength of correlations increased across the first 2 scales and then decreased at the largest scale (Fig. 7B).

Ecosystem service bundles were fairly robust across the two smaller scales and corresponded to an agriculture bundle, a multifunctional agricultural bundle with maple syrup and forest services, and an urban bundle with low levels of assessed services (Fig. 8). At the largest scale of observation, the bundling of the services was quite different, with several different mixes of agricultural dominance. However, the dominance of agricultural and forest-based services persisted.

In our comparison of the study area with the larger region (Fig. $8 \mathrm{~B}$ ), scale was kept constant, but bundles were impacted by changes in the number of ecosystem services and the number of municipalities analyzed. Changes in the number of ecosystem services included had minimal impact on the bundles identified, but bundles detected in the smaller study area were quite different from those detected across the entire region.

\section{DISCUSSION}

Effectively managing ecosystem services requires understanding the characteristic scales at which ecosystem services are produced, interact, and are consumed. The scales at which ecosystem services are observed or monitored fundamentally shape this understanding. Subsequently, we discuss how observation shapes ecosystem service mapping, trade-offs, and bundles and how different scales of production, consumption, and management can produce scale mismatches. We conclude with recommendations for how to better incorporate scale in the assessment and management of multiple ecosystem services.

\section{Scale of observation}

Our analysis demonstrates that scale of observation has substantial impact on our understanding of how ecosystem services occur on a landscape, less of an impact on patterns of correlations seen among ecosystem services, and a substantial impact on the identification of bundles of ecosystem services. In the case of some individual ecosystem services, e.g., crop production and forest recreation, patterns changed evenly across scales. For other ecosystem services, the pattern observed at the smallest scale was entirely hidden at the largest scale, e.g., pork production and nature appreciation.

Scale of observation has less influence on patterns observed for ecosystem services associated with extensive land covers and for any regulating ecosystem services that are produced at larger scales. Choosing a scale of analysis has more of an effect on patterns observed for cultural ecosystem services and provisioning ecosystem services not associated with extensive land covers, e.g., berries or wild fish, because these types of ecosystem services are characterized by presence/absence information and may be entirely absent in many parts of a 
Fig. 6. Patterns of seven ecosystem services assessed across three scales, representing different levels of how evenly the patterns change across scales. Grayscale shading maps equal interval quintiles, with darker shades representing higher ecosystem service provision.

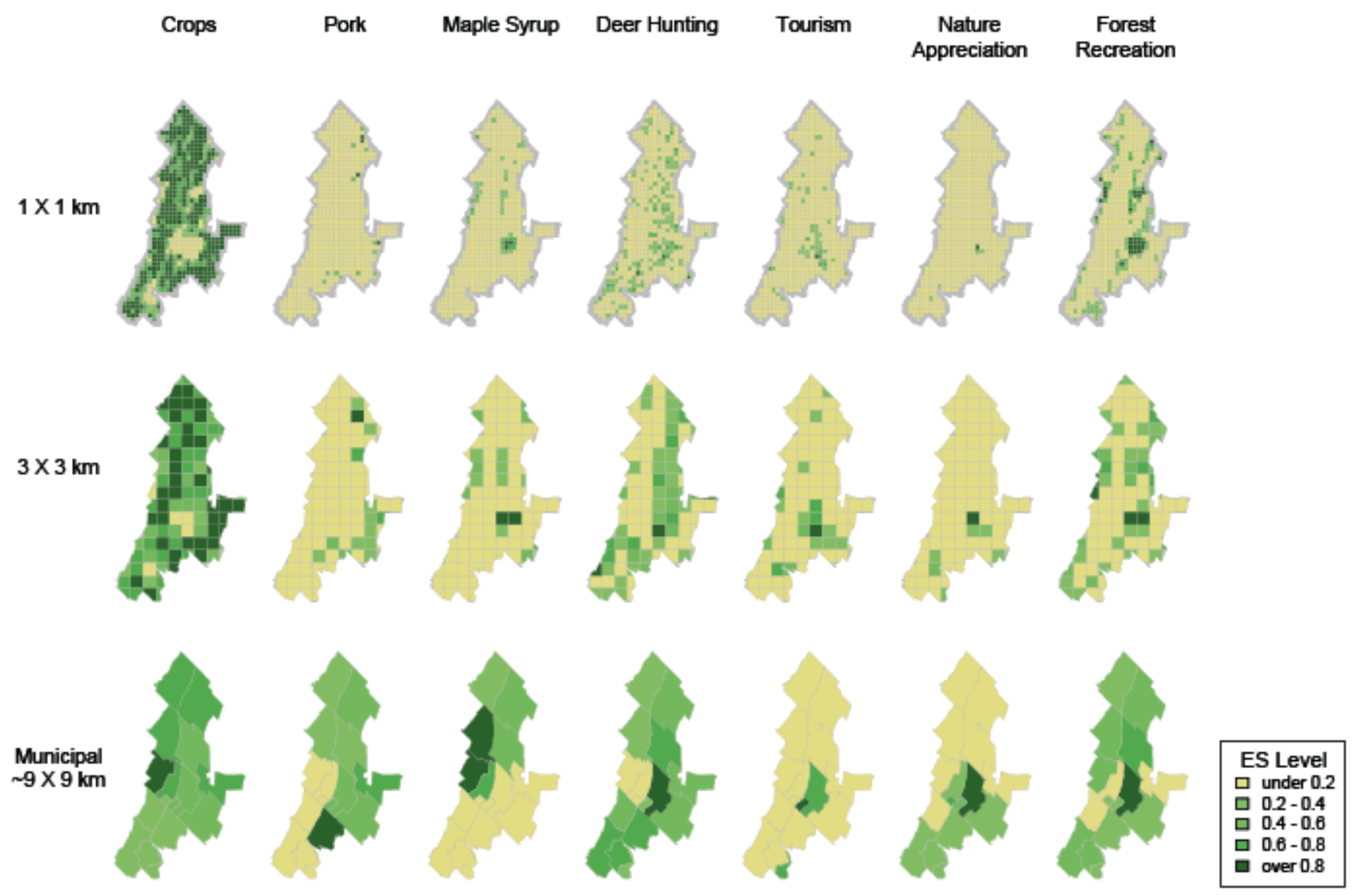

landscape. The spatial heterogeneity of the production of such ecosystem services is not visible at larger scales of observation (BDTQ 2005). Differences among scales of observation are particularly pronounced for ecosystem services that are spatially clustered in small portions of the landscape, such as deer hunting. Assessing the spatial clustering of an ecosystem service at a fine scale, for example using Moran's I, can be used to estimate which ecosystem services will be most misrepresented by observation at larger spatial scales (Moran 1950).

In our analysis, most relationships among ecosystem services are robust across scales. Changes in scale of observation did not greatly affect the number, strength, and type of correlation detected. This result is good news for trade-off analysis and management because data on ecosystem services are often scarce and scientists generally have to make do with whatever scale of data is available. Data availability restricted our analyses at the smaller scales to the MABR study site, a subset of the larger study region. Because the MABR comprised only 15 municipalities, interactions among ecosystem services at the largest scale were compared across the larger region (137 municipalities). We tested whether the same ecosystem service interactions could be observed if we only included the 15 municipalities within the MABR, or the 47 municipalities within the watershed holding the MABR. In both cases, 2 ecosystem service interactions remained the same, but many other interactions were no longer observed.

Analyses of ecosystem service bundles require careful consideration of what observation scale is appropriate because patterns of ecosystem service bundles were sensitive to changes in scale of observation. Within our study area, bundles were similar at the 2 finer resolutions, but they were quite different at the largest scale (municipalities; Fig. 8A). This implies that bundles can be somewhat robust to changes in scale of observation, but large changes may result in the reconfiguration of bundles. This is not surprising because what ecosystem services are present and how evenly they are spread across a landscape will influence the bundles that emerge. Ecosystem services that are heterogeneously distributed across a landscape are more likely to influence bundling in a larger study area if they are present in multiple areas, which is more likely at a larger scale of observation. For example, nature appreciation and deer hunting occur within 
Fig. 7. Strength of correlations between pairs of ecosystem services varies with scale of observation. (A) Pairwise correlations that increase in strength as scale increases. (B) Pairwise correlations that increase in strength with scale but then decrease at the highest scale, remaining significant. (C) Pairwise correlations that increase in strength as scale increases and then become insignificant at the highest scale. Appr., appreciation; Rec., recreation.
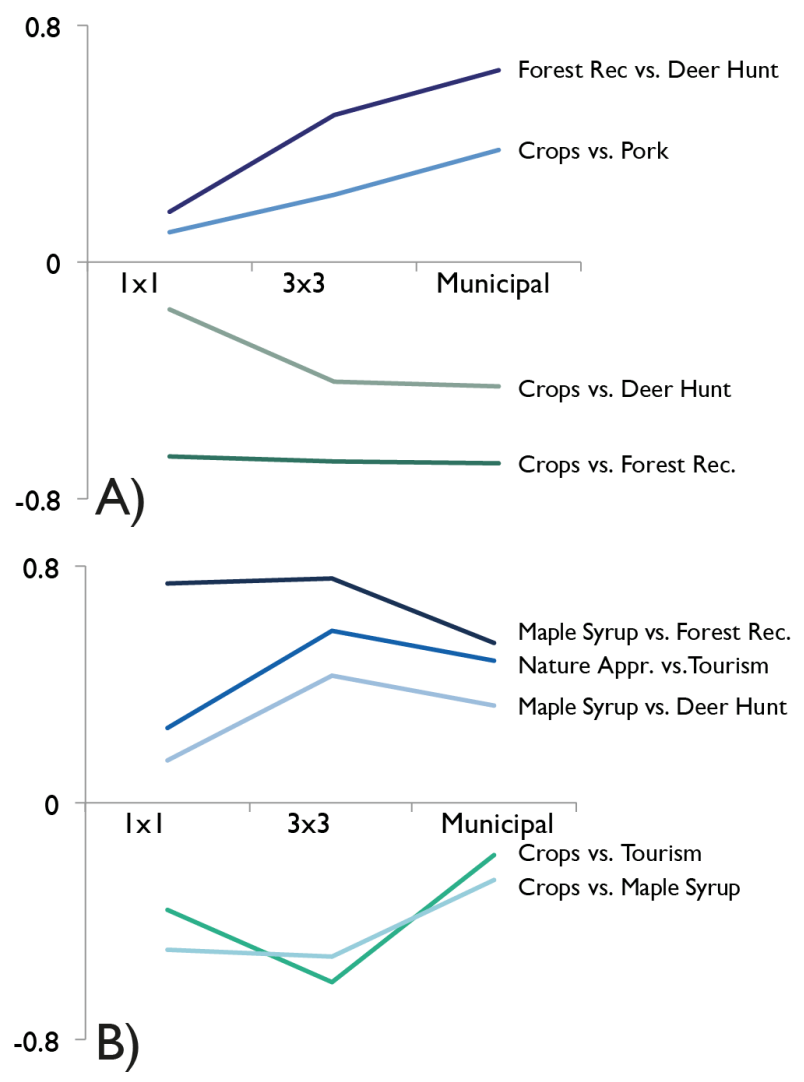

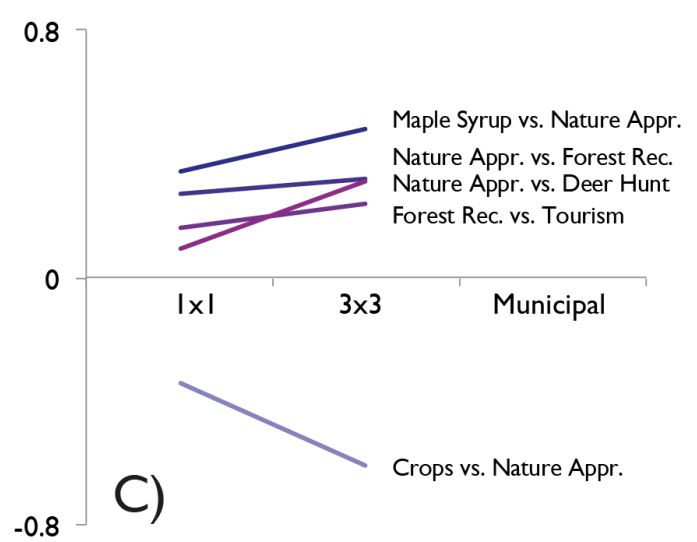

$-0.8$ very few of the $1-\mathrm{km}$ grid cells but are found in many municipalities, the largest scale of observation. Consequently, the bundles identified at finer scales are less multifunctional and more specialized than the bundles produced by the landscapes within municipalities; that is, many of the units at smaller scales do not contain any amount of certain ecosystem services, but some level of each service can be found at the municipal scale. Evenly distributed ecosystem services may influence bundling at all scales, e.g., forest cover or crop production.

Determining whether data sets at particular scales are adequate for capturing ecosystem service patterns will depend on the goals and purpose of an ecosystem assessment. For example, comparing the impact of farm management changes on ecosystem service production will require different types of information than a comparison of ecosystem services in municipalities across a region. Our results showed that factors that changed the identified patterns among ecosystem services include the following: the number of units across which ecosystem services were compared; the size of these units and how these units were defined, i.e., whether units were defined using an arbitrary $1 \times 1 \mathrm{~km}$ grid or using an integrated social-ecological border; and the heterogeneity among these units.
Consequently, detecting patterns among ecosystem services requires considering what type of units will represent an appropriate spatial grain for ecosystem service assessment and how many of those units are required to detect patterns among ecosystem services and units. Collecting and analyzing ecosystem service data within units that represent an entity in which multiple ecosystem service decisions are integrated, such as a watershed or municipality, is likely to provide results that are more meaningful for decision makers than units that are defined arbitrarily, such as Cartesian grid cells (Turner et al. 2014). Detecting patterns among ecosystem services and identifying bundles of ecosystem services depend on the intensity of the pattern relative to the variation among ecosystem services and units. Ecosystem service assessments should consider that observations from more units will be required to clearly define ecosystem service patterns when there is little variation among units (Queiroz et al. 2015, Meacham et al. 2016), but fewer observations are required when there is more variation among units (Yang et al. 2015).

\section{Ecosystem service scale mismatches}

We identified four types of management and production/ consumption scale mismatches in our case study landscape. These include the following: consumption $>$ production, production $>$ consumption, management $\neq$ production, and trade-off mismatch (Fig. 9). 
Fig. 8. (A) Bundles of ecosystem services identified at different scales of observation. (B) Bundles of ecosystem services identified at the municipal scale with different numbers of ecosystem services and across the larger region (Raudsepp-Hearne et al. 2010).

A)
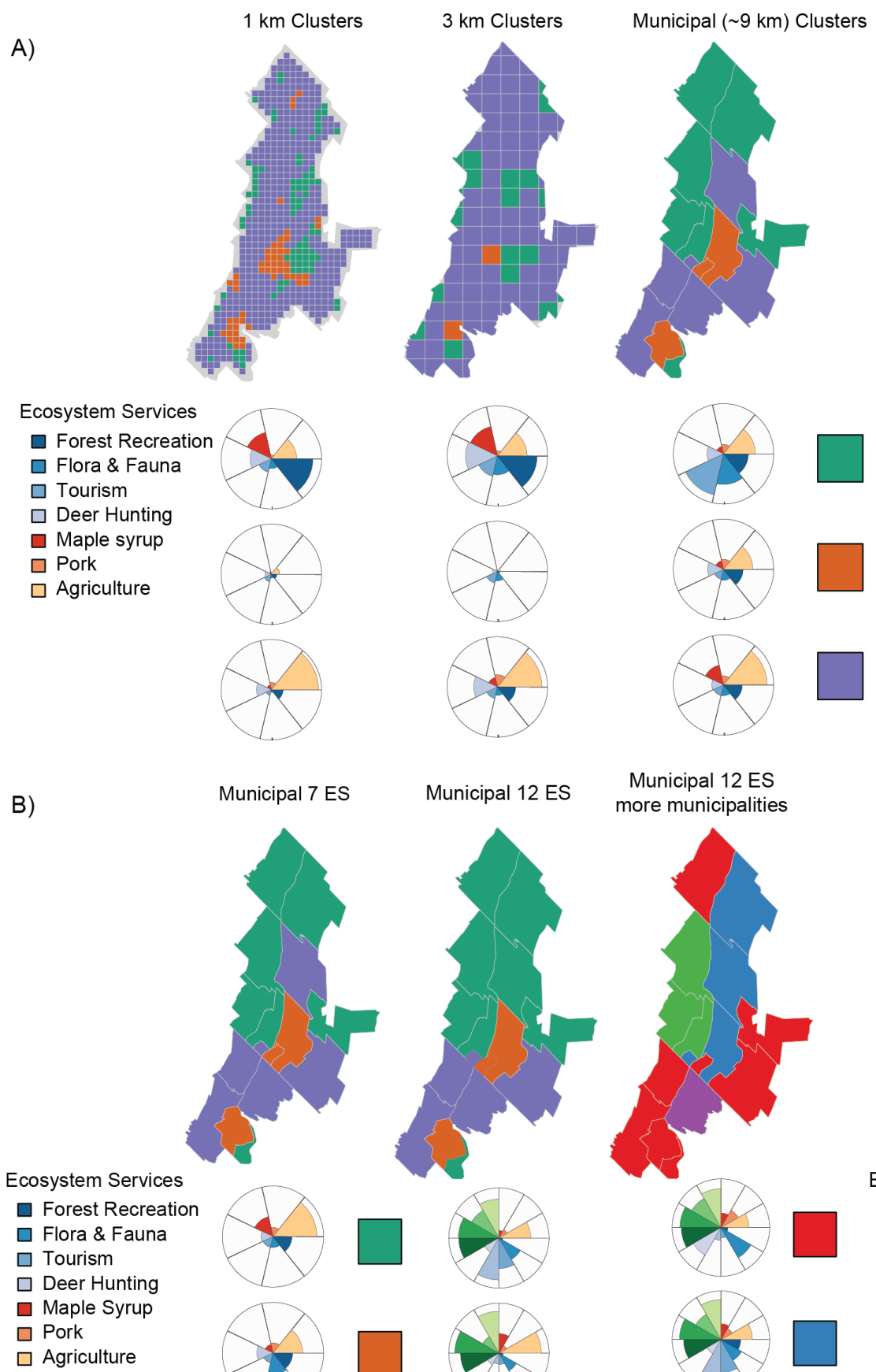

$$
\text { Municipal } 7 \text { ES }
$$

Municipal 12 ES

Municipal 12 ES
more municipalities
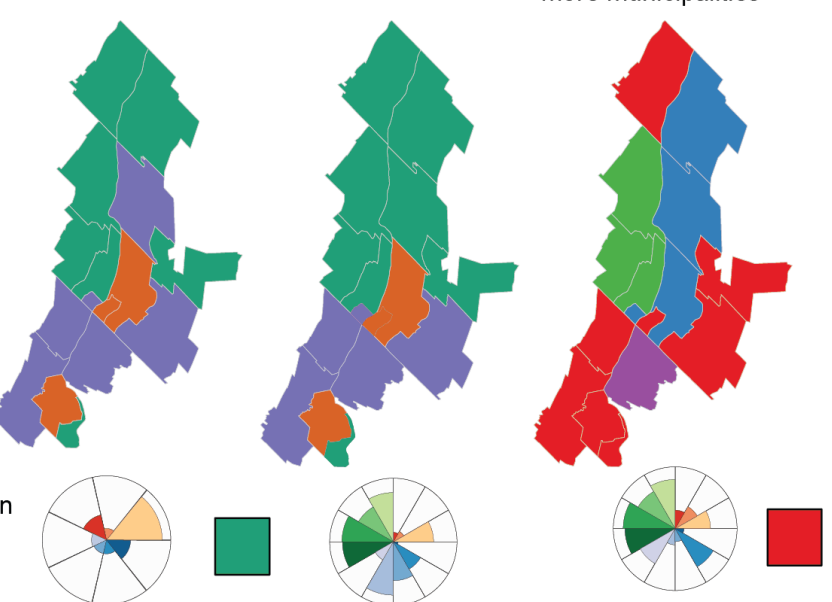

Ecosystem Services

$\square$ Summer Cottages

$\square$ Forest Recreation

$\square$ Flora \& Fauna

$\square$ Tourism

$\square$ Deer Hunting

$\square$ Organic Matter
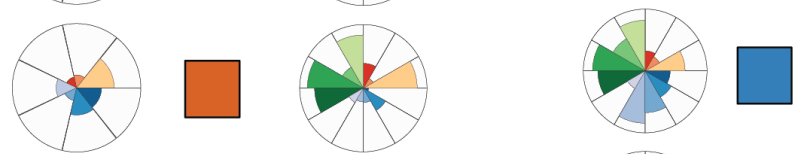

P Retention

$\square$ Carbon Sequestration

$\square$ Water Quality

$\square$ Maple Syrup
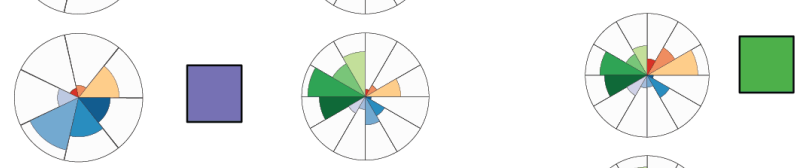

Pork

Agriculture 
Fig. 9. Ecosystem service scale mismatches can be produced by mismatches between production and benefit distribution (Fig. 1) or by mismatches between ecosystem management and production. Mismatches between ecosystem management and ecosystem service production can arise when either the management of a single ecosystem service does not match the scale of its production or when management activities impact multiple ecosystem services that are produced at different scales.

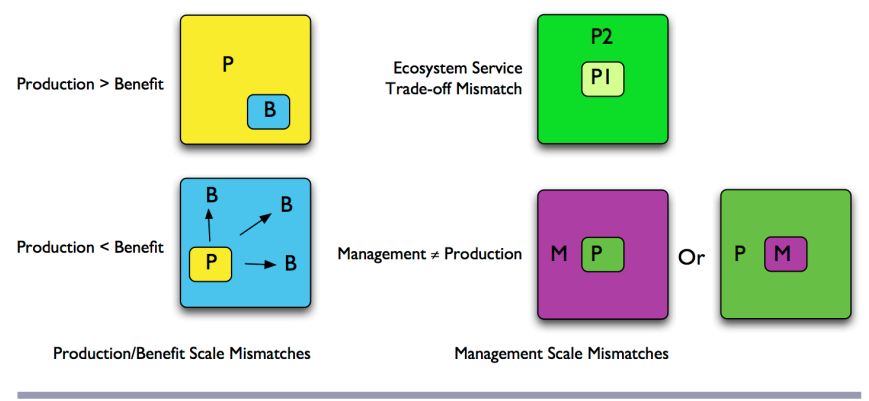

\section{Consumption $>$ production mismatch}

When an ecosystem service is produced at a scale smaller than the scale of consumption or use, there is no incentive for people at the smaller scale to manage that service. We observed two ecosystem services in the study area that exhibit this mismatch. In the clearest example, carbon sequestration benefits are consumed globally, even though it is at the level of the site that actions can be taken to influence carbon sequestration (Statistics Canada 2004). This mismatch could be eliminated by connecting the global consumption of carbon sequestration to local management via incentives to manage locally for carbon sequestration such as carbon markets, government subsidies (Wu 1999), or restrictions on activities that reduce sequestration.

\section{Production $>$ consumption mismatch}

When the scale of production is greater than the scale of consumption, there is a potential for a "tragedy of the commons" outcome. The widely used typology of relationships between ecosystem service production and benefits proposed by Fisher et al. (2009) does not identify this type of relationship; however, it occurs with six ecosystem services in our study system (see Fig. 5). For example, deer hunting is produced at the landscape to regional scale, but humans kill deer at specific sites. Individually, hunters have little incentive to manage deer populations at larger scales as long as they can continue to have hunting success. Cottages, forest recreation, and tourism may also exhibit this mismatch because they depend on the beauty, cultural character, and general appeal of the surrounding landscape. In these cases, the potential for conflict between producers and consumers is high, and there is a need for cross-scale cooperation and management. Because the production of ecosystem services is often unclear or poorly understood, education, social learning, and experimentation will often be needed to enable cross-scale cooperation (Folke et al. 2005, Carpenter et al. 2009, Cumming et al. 2013).

\section{Management $\neq$ production mismatch}

Management mismatches arise because the scale of management does not match the scale at which an ecosystem service is produced. Problems may develop when land managers at smaller or larger scales do not manage land in a way that supports the production of an ecosystem service. For example, water quality is produced at the watershed scale, but there is no effective body governing water quality at that scale in the study region. Actors and rules functioning at other scales may not be able to coordinate themselves to manage the service to produce desired outcomes.

\section{A trade-off mismatch}

Trade-off mismatches occur when there are trade-offs between services that are managed at different scales. This category is identified by combining observation scale with analyses of ecosystem service interactions. When ecosystem service production and consumption occur at the same scale, incentives are aligned for effective management, and signals from production provide direct feedback to those who are benefiting from and usually managing those services. However, trade-off mismatches can arise if there are trade-offs between a service being produced and other services that benefit people at different scales. In the study system, farmers have adequate incentives to manage the soil retention of phosphorus in their fields. Phosphorus is a costly input, and farmers are not allowed to increase phosphorus levels in their field above a critical threshold. However, soil retention of phosphorus, which is produced at the site scale, was observed to have trade-offs with water quality, which is produced at the watershed scale. In this case, cross-scale management is needed to reduce this trade-off. Watershed management organizations exist in the study region; however, these organizations are not effectively coordinating water management strategies across scales (Rathwell and Peterson 2012).

Our analytical combination of the concepts of scale mismatch and ecosystem service production and consumption yields some novel insights. Although the consumption $>$ production mismatch is identified in the widely used typology of relationships between ecosystem service production and benefits proposed by Fisher et al. (2009), the production $>$ consumption mismatch is missing from their typology. Similarly, the scale mismatch concept (Cumming et al. 2006) has been applied to scale mismatches between ecological and social processes, but trade-off mismatches that can arise from the mix of scales of production and management among multiple ecosystem services had not been identified. We propose using these additional types of mismatches to evaluate and improve existing or proposed approaches to the management of multiple ecosystem services.

\section{General implications for ecosystem service assessment}

To facilitate the relevance and implementation of ecosystem service assessment results by managers, a general principle has emerged to assess ecosystem services at the scale of political or management boundaries (Gitay et al. 2005, Raudsepp-Hearne et al. 2010). Assessment results need to fit the needs of decision makers, but they also need to capture social-ecological complexities. Based on this cross-scale case study, we propose four ways that considerations of scale could be used to improve ecosystem service assessments. 
First, the scale of both social and ecological processes should be considered in designing ecosystem service assessments. We propose that in addition to using social-ecological units of analysis, ecosystem service analyses should begin with a quick exploration of the scales at which each ecosystem service of interest is produced, consumed, and managed (see Methods for how to do this). To connect the production of services to their use, scientists need a social-ecological lens to identify how the services are being consumed and managed. Choice of scale should take ecosystem service consumption and management into account, and not just the ecological dynamics of ecosystem services. The scale of ecosystem service consumption can often be identified by looking at ecosystem service management because management tends to occur where there is a demand for the services or a need to manage trade-offs among services. Although such an approach will often not identify all ecosystem service consumption, it provides an effective start to such an assessment.

Second, scale mismatches occur frequently and should be a focus of assessment. Mismatches can be identified informally by comparing what is already known about the scales of ecosystem service processes in a study area and supplemented where necessary with research and consultation. Our typology of scale mismatches can be used to screen ecosystem services. Identifying scale mismatches can focus an assessment on issues or places for intervention in a system, for example areas where management incentives or feedbacks are lacking, or where conflicts are occurring among stakeholders at different scales. Addressing scale mismatches can be difficult, but in at least some cases, solutions to scale mismatches are simple, such as monitoring programs or better communication between producers and managers.

Third, ecosystem services scale differently. Our results suggest that ecosystem services whose production is more evenly distributed will behave more consistently across scales, and those with patchier distributions are more likely to require greater attention when choosing an assessment scale. Some ecosystem services are tightly associated with land cover, for example crop production and forest recreation. Land covers that are extensive tend to change evenly across scales because local configuration does not influence scaling (Turner 2010). Cultural and provisioning ecosystem services that are not associated with extensive land covers, e.g., wild berries, recreation, or hunting, are types of ecosystem services that will likely have unpredictable and very patchy distributions on the landscape. Ecosystem services that are dependent on people's access to the particular landscape elements, e.g., recreation, hunting, or wild food collection, may also occur in patchy distributions that may not be observed at larger scales. For example, different forms of nature appreciation are possible in areas with unique ecological features but are restricted to areas that are accessible to the public. Mapping is the easiest and most effective way of identifying any ecosystem services with very heterogeneous distributions, but as more ecosystem services are assessed, it will become easier to know what type of ecosystem service distribution to expect in a particular place. If ecosystem services are extremely clustered or sparsely distributed, analysis at some scales will not capture their true patterns. The most appropriate scale for mapping those ecosystem services on the landscape should therefore be decided based on the questions being asked and the type of detail and analysis required.

Fourth, how patterns of multiple ecosystem services change across scales is related to the amount of social-ecological heterogeneity of the landscape. Ecosystem service bundles are clustered across space because similar sets of services are produced in similar landscapes or in particular areas on a landscape. Social institutions, geographic features, and economic dynamics interact to produce different types of social-ecological systems, where different types of ecosystem service bundles can be found. It is only within this social-ecological understanding of the diversity and heterogeneity within a landscape that bundle analysis results can be interpreted. For example, ecosystem services in our study landscape are shaped by distance from Montréal, the river network geography, and the development of cultural centers for recreation, art, and sport. Understanding these social-ecological interactions can help define useful scales of analysis by identifying scales that capture variation in these structures and feedback processes.

\section{CONCLUSION}

We present a novel analysis of how the scale of observation in ecosystem service assessment matters. We analyzed patterns of ecosystem services at multiple scales and show that although there is consistency in trade-offs and synergies across scales, changes in the scale of observation of services alters the bundles of ecosystem services that are identified in a landscape. We identified novel potential scale mismatches on the landscape and suggest that these typologies could be used to guide and evaluate other ecosystem service assessments.

As ecosystem services become more entrenched in policy responses to environmental degradation, it is clear that scientists need to provide more precise and relevant information on which to build appropriate policy responses. Understanding at what scale ecosystem services are produced, managed, consumed, and accessed is essential for designing ecosystem service monitoring and management strategies that are effective, accurate, and fair.

Responses to this article can be read online at: http://www.ecologyandsociety.org/issues/responses. $\mathrm{php} / 8605$

\section{Acknowledgments:}

This work was supported by a scholarship from the Natural Sciences and Engineering Research Council of Canada (C. RaudseppHearne) and a Canada Research Chair (G. D. Peterson). We thank the subject editor and the anonymous reviewers for their useful comments, and we are grateful to Toby Harper-Merrett for his constructive feedback and edits.

\section{LITERATURE CITED}

Andersson, E., S. Barthel, and K. Ahrné. 2007. Measuring socialecological dynamics behind the generation of ecosystem services. Ecological Applications 17(5):1267-1278. http://dx.doi. org/10.1890/06-1116.1 
Base de données topographiques du Québec (BDTQ). 2005. Québec topographic database - base de données topographiques du Québec (BDTQ), 1:20 000. Ministère des Ressources Naturelles et Faune, Québec, Québec, Canada.

Beauchemin, S., and R. R. Simard. 2000. Phosphorus status of intensively cropped soils of the St. Lawrence Lowlands. Soil Science Society of America Journal 64:659-670. http://dx.doi. org/10.2136/sssaj2000.642659x

Bennett, E. M., W. Cramer, A. Begossi, G. Cundill, S. Díaz, B. N. Egoh, I. R. Geijzendorffer, C. B. Krug, S. Lavorel, E. Lazos, L. Lebel, B. Martín-López, P. Meyfroidt, H. A. Mooney, J. L. Nel, U. Pascual, K. Payet, N. P. Harguindeguy, G. D. Peterson, A.-H. Prieur-Richard, B. Reyers, P. Roebeling, R. Seppelt, M. Solan, P. Tschakert, T. Tscharntke, B. L. Turner II, P. H. Verburg, E. F. Viglizzo, P. C. L. White, and G. Woodward. 2015. Linking biodiversity, ecosystem services, and human well-being: three challenges for designing research for sustainability. Current Opinion in Environmental Sustainability 14:76-85. http://dx.doi. org/10.1016/j.cosust.2015.03.007

Bennett, E. M., G. D. Peterson, and L. J. Gordon. 2009. Understanding relationships among multiple ecosystem services. Ecology Letters 12(12):1394-1404. http://dx.doi.org/10.1111/ j.1461-0248.2009.01387.X

Bivand, R., and N. Lewin-Koh. 2013. Maptools: tools for reading and handling spatial objects. $\mathrm{R}$ package version $0.8-27$. $\mathrm{R}$ Foundation for Statistical Computing, Vienna, Austria. [online] URL: http://CRAN.R-project.org/package=maptools

Bivand, R. S., E. Pebesma, and V. Gómez-Rubio. 2013. Applied spatial data analysis with $R$. Second edition. Springer, New York, New York, USA. http://dx.doi.org/10.1007/978-1-4614-7618-4

Brauman, K. A., G. C. Daily, T. K. Duarte, and H. A. Mooney. 2007. The nature and value of ecosystem services: an overview highlighting hydrologic services. Annual Review of Environment and Resources 32:67-98. http://dx.doi.org/10.1146/annurev. energy.32.031306.102758

Carpenter, S. R., H. A. Mooney, J. Agard, D. Capistrano, R. S. DeFries, S. Díaz, T. Dietz, A. K. Duraiappah, A. Oteng-Yeboah, H. M. Pereira, C. Perrings, W. V. Reid, J. Sarukhan, R. J. Scholes, and A. Whyte. 2009. Science for managing ecosystem services: beyond the Millennium Ecosystem Assessment. Proceedings of the National Academy of Sciences of the United States of America 106:1305-1312. http://dx.doi.org/10.1073/pnas.0808772106

Centre de Données sur le Patrimoine Naturel du Québec (CDPNQ). 2007. Extractions du système de données pour le territoire de la Montérégie, de l'Estrie et du Centre-du-Québec. CDPNQ, Ministère du Développement durable, Québec, Québec, Canada.

Chan, K. M. A., M. R. Shaw, D. R. Cameron, E. C. Underwood, and G. C. Daily. 2006. Conservation planning for ecosystem services. PLoS Biology 4(11):e379. http://dx.doi.org/10.1371/ journal.pbio.0040379

Chapin, F. S., III, M. D. Robards, H. P. Huntington, J. F. Johnstone, S. F. Trainor, G. P. Kofinas, R. W. Ruess, N. Fresco, D. C. Natcher, and R. L. Naylor. 2006. Directional changes in ecological communities and social-ecological systems: a framework for prediction based on Alaskan examples. American Naturalist 168(S6):S36-S49. http://dx.doi.org/10.1086/509047

Conroy, M. J., C. R. Allen, J. T. Peterson, L. Pritchard, and C. T. Moore. 2003. Landscape change in the southern Piedmont: challenges, solutions, and uncertainty across scales. Conservation Ecology 8(2):3. [online] URL: http://www.consecol.org/vol8/iss 2/ $\underline{\operatorname{art} 3}$

Cumming, G. S., D. H. M. Cumming, and C. L. Redman. 2006. Scale mismatches in social-ecological systems: causes, consequences, and solutions. Ecology and Society 11(1):14. [online] URL: http://www.ecologyandsociety.org/vol11/iss1/ $\underline{\operatorname{art} 14 /}$

Cumming, G. S., P. Olsson, F. S. Chapin III, and C. S. Holling. 2013. Resilience, experimentation, and scale mismatches in socialecological landscapes. Landscape Ecology 28(6):1139-1150. http://dx.doi.org/10.1007/s10980-012-9725-4

Cumming, G. S., and B. J. Spiesman. 2006. Regional problems need integrated solutions: pest management and conservation biology in agroecosystems. Biological Conservation 131:533-543. http://dx.doi.org/10.1016/j.biocon.2006.02.025

Daily, G. C. 1997. Nature's services: societal dependence on natural ecosystems. Island, Washington, D.C., USA.

de Groot, R. S., R. Alkemade, L. Braat, L. Hein, and L. Willemen. 2010. Challenges in integrating the concept of ecosystem services and values in landscape planning, management and decision making. Ecological Complexity 7:260-272. http://dx.doi. org/10.1016/j.ecocom.2009.10.006

Egoh, B., B. Reyers, M. Rouget, D. M. Richardson, D. C. Le Maitre, and A. S. van Jaarsveld. 2008. Mapping ecosystem services for planning and management. Agriculture, Ecosystems \& Environment 127:135-140. http://dx.doi.org/10.1016/j.agee.2008.03.013

Fisher B., R. K. Turner, and P. Morling. 2009. Defining and classifying ecosystem services for decision making. Ecological Economics 68:643-653. http://dx.doi.org/10.1016/j.ecolecon.2008.09.014

Folke, C., T. Hahn, P. Olsson, and J. Norberg. 2005. Adaptive governance of social-ecological systems. Annual Review of Environment and Resources 30:441-473. http://dx.doi.org/10.1146/ annurev.energy.30.050504.144511

Gibson, C. C., E. Ostrom, and T. K. Ahn. 2000. The concept of scale and the human dimensions of global change: a survey. Ecological Economics 32:217-239. http://dx.doi.org/10.1016/ $\underline{\text { S0921-8009(99)00092-0 }}$

Gitay, H., C. Raudsepp-Hearne, H. Blanco, K. Garcia, and H. Pereira. 2005. Assessment process. Pages 119-140 in D. Capistrano, C. Samper, M. J. Lee, and C. Raudsepp-Hearne, editors. Ecosystems and human well-being. Volume 4, multiscale assessments. Island, Washington, D.C., USA.

Hein, L., K. van Koppen, R. S. de Groot, and E. C. van Ierland. 2006. Spatial scales, stakeholders and the valuation of ecosystem services. Ecological Economics 57:209-228. http://dx.doi. org/10.1016/j.ecolecon.2005.04.005

Hennig, C. 2013. fpc: flexible procedures for clustering. R package version 2.1-6. R Foundation for Statistical Computing, Vienna, Austria. [online] URL: http://CRAN.R-project.org/package= $\underline{f p c}$ 
Holland, R. A., F. Eigenbrod, P. R. Armsworth, B. J. Anderson, C. D. Thomas, A. Heinemeyer, S. Gillings, D. B. Roy, and K. J. Gaston. 2011. Spatial covariation between freshwater and terrestrial ecosystem services. Ecological Applications 21 (6):2034-2048. http://dx.doi.org/10.1890/09-2195.1

Institut de la Statistique du Québec(ISQ). 2007. Biofood industrycrop production 2001. ISQ, Québec, Québec, Canada.

Kleinman, P. J. A., and A. N. Sharpley. 2002. Estimating soil phosphorus sorption saturation from Mehlich-3 data. Communications in Soil Science and Plant Analysis 33:1825-1839. http://dx.doi.org/10.1081/CSS-120004825

Land Processes Distributed Active Archive Center (LPDAAC). 2001. MODIS/Terra Net Photosynthesis 8-Day L4 Global $1 \mathrm{~km}$ SIN Grid. MOD17A2. Version V004. January 1, 2001 - December 31, 2001. LPDAAC, U.S. Geological Survey Earth Resources Observation and Science Center, Sioux Falls, South Dakota, USA. [online] URL: http://LPDAAC.usgs.gov

Lant, C. L., S. E. Kraft, J. Beaulieu, D. Bennett, T. Loftus, and J. Nicklow. 2005. Using GIS-based ecological-economic modeling to evaluate policies affecting agricultural watersheds. Ecological Economics 55:467-484. http://dx.doi.org/10.1016/j.ecolecon.2004.12.006

Loveland, P., and J. Webb. 2003. Is there a critical level of organic matter in the agricultural soils of temperate regions: a review. Soil and Tillage Research 70:1-18. http://dx.doi.org/10.1016/ $\underline{\mathrm{S} 0167-1987(02) 00139-3}$

Malinga, R., L. J. Gordon, G. Jewitt, and R. Lindborg. 2015. Mapping ecosystem services across scales and continents - a review. Ecosystem Services 13:57-63. http://dx.doi.org/10.1016/j. ecoser.2015.01.006

Martín-López, B., E. Gómez-Baggethun, P. L. Lomas, and C. Montes. 2009. Effects of spatial and temporal scales on cultural services valuation. Journal of Environmental Management 90 (2):1050-1059. http://dx.doi.org/10.1016/j.jenvman.2008.03.013

Meacham, M., C. Queiroz, A. Norström, and G. Peterson. 2016. Social-ecological drivers of multiple ecosystem services: what variables explain patterns of ecosystem services across the Norström drainage basin? Ecology and Society 21(1):14. http:// dx.doi.org/10.5751/ES-08077-210114

Millennium Ecosystem Assessment (MA). 2003. Ecosystems and human well-being: a framework for assessment. Island, Washington, D.C., USA.

Millennium Ecosystem Assessment (MA). 2005a. Ecosystems and human well-being. Volume 1, current state and trends. Island, Washington, D.C., USA.

Millennium Ecosystem Assessment (MA). 2005b. Ecosystems and human well-being. Volume 4, multiscale assessments. Island, Washington, D.C., USA.

Ministère de l'Agriculture, des Pêcheries et de l'Alimentation du Québec (MAPAQ). 2001. Description statistique des propriétés chimiques des sols minéraux du Québec: basee sur les analyses de sols effectuées de 1995-2001. MAPAQ, Direction de l'environment et du développement durable, Québec, Québec, Canada.
Ministère des Affaires municipales et des Régions (MAMR). 2007. Données sur les roles d'évaluation foncière pour chacune des municipalites. MAMR, Québec, Québec, Canada.

Ministère du Développement durable, de l'Environnement et des Parcs (MDDEP). 2008. Banque de données sur la qualité du milieu aquatique (BQMA). MDDEP, Direction du suivi de l'état de l'environnement, Québec, Québec, Canada.

Ministère du Tourisme Québec (MTQ). 2007a. Critères d'admissibilité à la banque de données sur les produits et services touristiques. MTQ, Québec, Québec, Canada.

Ministère du Tourisme Québec (MTQ). 2007b. Données sur les sites touristiques du Québec. MTQ, Québec, Québec, Canada.

Moran, P. A. P. 1950. Notes on continuous stochastic phenomena. Biometrika 37:17-33. http://dx.doi.org/10.1093/biomet/37.1-2.17

Neuwirth, E. 2011. RColorBrewer: ColorBrewer palettes. R package version 1.0-5. R Foundation for Statistical Computing, Vienna, Austria. http://CRAN.R-project.org/package=RColorBrewer

Oksanen, J., F. Guillaume Blanchet, M. Friendly, R. Kindt, P. Legendre, D. McGlinn, P. R. Minchin, R. B. O'Hara, G. L. Simpson, P. Solymos, M. H. H. Stevens, E. Szoecs, and H. Wagner. 2013. vegan: community ecology package. R package version 2.0-9. R Foundation for Statistical Computing, Vienna, Austria. http:// CRAN.R-project.org/package $=$ vegan

O'Neill, R. V., A. R. Johnson, and A. W. King. 1989. A hierarchical framework for the analysis of scale. Landscape Ecology 3:193-205. http://dx.doi.org/10.1007/BF00131538

Queiroz, C., M. Meacham, K. Richter, A. V. Norström, E. Andersson, J. Norberg, and G. Peterson. 2015. Mapping bundles of ecosystem services reveals distinct types of multifunctionality within a Swedish landscape. AMBIO44(S1):89-101. http://dx.doi. org/10.1007/s13280-014-0601-0

Rathwell, K. J., and G. D. Peterson. 2012. Connecting social networks with ecosystem services for watershed governance: a social-ecological network perspective highlights the critical role of bridging organizations. Ecology and Society 17(2):24. http:// dx.doi.org/10.5751/es-04810-170224

Raudsepp-Hearne, C., G. D. Peterson, and E. M. Bennett. 2010. Ecosystem service bundles for analyzing tradeoffs in diverse landscapes. Proceedings of the National Academy of Sciences of the United States of America 107(11):5242-5247. http://dx.doi. org/10.1073/pnas.0907284107

R Core Team. 2014. R: a language and environment for statistical computing. R Foundation for Statistical Computing, Vienna, Austria. [online] URL: http://www.R-project.org/

Reid, W. V., F. Berkes, T. Wilbanks, and D. Capistrano. 2006. Bridging scales and knowledge systems: concepts and applications in ecosystem assessment. Island, Washington, D.C., USA.

Reyers, B., R. Biggs, G. S. Cumming, T. Elmqvist, A. P. Hejnowicz, and S. Polasky. 2013. Getting the measure of ecosystem services: a social-ecological approach. Frontiers in Ecology and the Environment 11(5):268-273. http://dx.doi.org/10.1890/120144

Scholes, R. J., B. Reyers, R. Biggs, M. J. Spierenburg, and A. Duriappah. 2013. Multi-scale and cross-scale assessments of 
social-ecological systems and their ecosystem services. Current Opinion in Environmental Sustainability 5(1):16-25. http://dx.doi. org/10.1016/j.cosust.2013.01.004

SoftMap. 2001. The guide to fishing and hunting in Québec. SoftMap Inc., Québec, Québec, Canada.

Statistics Canada. 2001a. Table 5: land in crops (excluding Christmas tree area) by hectare, by province, census consolidated subdivision (CCS), 2001 Québec. In 2001 Census of Agriculture, land use, by province, census agricultural region (CAR), census division (CD) and census consolidated subdivision (CCS) [database]. Statistics Canada, Ottawa, Ontario, Canada.

Statistics Canada. 2001b. Table 18: number of taps on maple trees by number of taps on maple trees, by province, census consolidated subdivision (CCS), 2001 Québec. In 2001 Census of Agriculture, maple tree taps, by province, census agricultural region (CAR), census division (CD) and census consolidated subdivision (CCS) [database]. Statistics Canada, Ottawa, Ontario, Canada.

Statistics Canada. 2001c. Table 20: pigs by number of pigs, by province, census consolidated subdivision (CCS), 2001 Québec. In 2001 Census of Agriculture, pigs, by province, census agricultural region (CAR), census division (CD) and census consolidated subdivision (CCS) [database]. Statistics Canada, Ottawa, Ontario, Canada.

Statistics Canada. 2001d. Table 13: total corn, soya, hay, wheat, beans, oats, barley, mixed grains by hectare, by province, census consolidated subdivision (CCS), 2001 Québec. In 2001 Census of Agriculture, hay and field crops, by province, census agricultural region (CAR), census division (CD) and census consolidated subdivision (CCS) [database]. Statistics Canada, Ottawa, Ontario, Canada.

Statistics Canada. 2004. Canadian agriculture at a glance. Minister of Industry, Ottawa, Ontario, Canada.

Summers, P. M., J. O. Browder, and M. A. Pedlowski. 2004. Tropical forest management and silvicultural practices by small farmers in the Brazilian Amazon: recent farm-level evidence from Rondônia. Forest Ecology and Management 192:161-177. http:// dx.doi.org/10.1016/j.foreco.2003.12.016

Tallis, H., and S. Polasky. 2009. Mapping and valuing ecosystem services as an approach for conservation and natural-resource management. Annals of the New York Academy of Sciences 1162:265-283. http://dx.doi.org/10.1111/j.1749-6632.2009.04152. $\underline{x}$

Tscharntke, T., A. M. Klein, A. Kruess, I. Steffan-Dewenter, and C. Thies. 2005. Landscape perspectives on agricultural intensification and biodiversity - ecosystem service management. Ecology Letters 8:857-874. http://dx.doi.org/10.1111/ j.1461-0248.2005.00782.x

Turner, M. G. 2010. Disturbance and landscape dynamics in a changing world. Ecology 91:2833-2849. http://dx.doi. org/10.1890/10-0097.1

Turner, R. K., and G. C. Daily. 2008. The ecosystem services framework and natural capital conservation. Environmental \& Resource Economics 39:25-35. http://dx.doi.org/10.1007/ $\underline{\text { s10640-007-9176-6 }}$
Turner, K. G., M. V. Odgaard, P. K. Bøcher, T. Dalgaard, and J.C. Svenning. 2014. Bundling ecosystem services in Denmark: trade-offs and synergies in a cultural landscape. Landscape and Urban Planning 125:89-104. http://dx.doi.org/10.1016/j. landurbplan.2014.02.007

van Jaarsveld, A. S., R. Biggs, R. J. Scholes, E. Bohensky, B. Reyers, T. Lynam, C. Musvoto, and C. Fabricius. 2005. Measuring conditions and trends in ecosystem services at multiple scales: the Southern African Millennium Ecosystem Assessment (SAfMA) experience. Philosophical Transactions of the Royal Society B: Biological Sciences 360:425-441. http://dx.doi.org/10.1098/ rstb.2004.1594

Vermaat, J. E., F. Eppink, J. C. J. M. van den Bergh, A. Barendregt, and J. van Belle. 2005. Aggregation and the matching of scales in spatial economics and landscape ecology: empirical evidence and prospects for integration. Ecological Economics 52:229-237. http://dx.doi.org/10.1016/j.ecolecon.2004.06.027

Whalen, J. K., H. Quancai, and L. Aiguo. 2003. Compost applications increase water-stable aggregates in conventional and no-tillage systems. Soil Science Society of America Journal 67:1842-1847. http://dx.doi.org/10.2136/sssaj2003.1842

Wu, J. 1999. Hierarchy and scaling: extrapolating information along a scaling ladder. Canadian Journal of Remote Sensing 25:367-380. http://dx.doi.org/10.1080/07038992.1999.10874736

Yang, G., Y. Ge, H. Xue, W. Yang, Y. Shi, C. Peng, Y. Du, X. Fan, Y. Ren, and J. Chang. 2015. Using ecosystem service bundles to detect trade-offs and synergies across urban-rural complexes. Landscape and Urban Planning 136:110-121. http://dx.doi. org/10.1016/j.landurbplan.2014.12.006 
Appendix 1. Details of quantification of ecosystem services at three scales.

\section{MUNICIPAL SCALE}

Information for crops, pork and maple syrup was taken from the 2001 Canadian Agricultural Census, which provides data at the level of municipalities. In the Agricultural Census, these are called Census Consolidated Subdivisions (CCS). CCS represent single municipalities, or in some cases the consolidation of several municipalities if the municipalities in question are judged to have too few farms to allow the privacy of individual farmers to be protected. In order to extract information on individual municipalities from CCS, ES values were estimated for individual municipalities by weighting the CCS values by area of the consolidated municipalities.

\section{Crops (\% of municipal land dedicated to crop production)}

Crop production was estimated using 2001 Canadian Agricultural Census data (Statistics Canada 2001a). The category 'Land under Crop' gives the amount of hectares under cultivation. Land under crop was chosen as an indicator because crop yield values were less comparable across the two watersheds due to differences in crop plants. Land under cultivation is an indicator of how important agriculture is to each municipality, in terms of how much land in total is dedicated to this economic activity.

\section{Pork (number of pigs produced per $\mathrm{km}^{2}$ )}

Pork production data were taken from the 2001 Canadian Agricultural Census (Statistics Canada 2001c). Due to privacy protection laws, in some cases the number of pork-producing farms was available, but the number of pigs produced on these farms was not. In these cases, the average number of pigs per farm in all of the surrounding municipalities (those that touched the municipality in question) was used to estimate the number of pigs per farm, and thus the total number of pigs produced.

\section{Drinking water (rank 1-5, including non-integers where average values were calculated from more than one sampling station)}

The provision of drinking water was estimated from a provincial government water quality database (MDDEP 2008). The majority of water for drinking in the region is harvested from surface waters where water quality testing stations are set up. We used a water quality index called the IQBP (indice de qualité bactériologique et physico-chimique) that is used by the provincial government to assess the raw water supply intended for consumption. The index is based on conventional 
physicochemical and bacteriological water quality parameters and combines eight variables: phosphorus, fecal coliforms, turbidity, ammonia nitrogen, nitrates/nitrites, chlorophyll a, dissolved oxygen, and $\mathrm{pH}$.

Long-term water quality data from the government database was available throughout the watershed, but only on the main stems of rivers and their major tributaries. Values for 2001 were estimated by calculating the average of all water quality samples taken in that year. To estimate water quality values for municipalities that touched rivers where samples were taken, IQBP values from stations falling within each municipality were used. If more than one sampling station fell within a municipality, the average values of water quality across sampling stations was calculated. In cases where municipalities did not touch a river where sampling was done, one of two methods was used to estimate a value for water quality: 1) municipalities drawing their drinking water from a known location and treatment plant were assigned water quality values for the area of river where the water is drawn from, or 2) municipalities not drawing their drinking water from surface water were assigned a neutral value of 3.5 (not considered to be good or bad water quality).

\section{Maple syrup (number of maple syrup taps per $\mathbf{k m}^{2}$ )}

Maple syrup production was estimated using the 2001 Canadian Agricultural Census (Statistics Canada 2001b). This dataset gives the number of maple syrup taps and maple syrup farms for each municipality. Maple syrup taps was chosen as an indicator of production, as the size of each maple syrup farm varied widely. Due to privacy protection laws, in some cases the number of maple syrup-producing farms was available, but not the number of maple syrup taps. In these cases, the average number of taps per farm in all surrounding municipalities (those that touched the municipality in question) was used to estimate the number of maple syrup taps per farm, and thus the total number of taps.

\section{Deer hunting (number of deer killed per $\mathbf{k m}^{2}$ )}

Hunting data was obtained from database called The Guide to Hunting and Fishing in Quebec, developed by a private mapping company (SoftMap 2001). Data from 1999 was used that identifies the location of every deer killed that year. Hunters are required to mark on a map the location where they shot the deer when they register the dead deer at their local tagging station. In ArcGIS, the number of points where deer were killed was calculated for each municipal polygon.

\section{Tourist attractions (number of tourist attractions per $\mathbf{k m}^{2}$ )}


The number of tourist attractions per municipality was estimated using a provincial government database (MTQ 2007b). A document accompanying the database lists the criteria used to determine whether a site is included in the tourism database (criteria include factors such as having infrastructure aimed at hosting tourists, being registered with the provincial regulating body, conforming with local and provincial laws and regulations, etc, as well as more specific criteria pertaining to types of tourist sites) (MTQ 2007a). Estimations of the number of tourist attractions per municipality included only tourist attractions themselves and not related services such as restaurants and lodging.

\section{Nature appreciation (number of reported sightings of rare species per $\mathbf{k m}^{2}$ )}

This data was collected by the MDDEP (Ministry for Sustainable Development, Environment and Parks) and the MRNF (Ministry for Natural Resources and Fauna) from 1988 to 2007 and was available as a shapefile for the region requested (CDPNQ 2007). The number of points where rare species of flora and fauna were observed was calculated in ArcGIS for each municipal polygon. This data includes observations of endangered or threatened floral and faunal species within the two study watersheds (in accordance with classifications under CITES). Observations are not considered to represent an accurate portrait of rare and endangered species in the region, but rather a reflection of areas that have been frequented by scientists and nature enthusiasts and where these species were observed.

\section{Summer cottages (tax value of cottages per $\mathbf{k m}^{2}$ )}

Data for estimating values of summer cottages was taken from a provincial database on property taxes by category of lodging (MAMR 2007). The summer cottage category of housing (category $\mathrm{K}$ - chalet) was available by municipality. Additional data on the number of summer cottages per municipality was collected from each municipality by calling all municipal offices, in order to check whether the tax value data reflected the extent of this land use. Tax value of cottages and number of cottages were highly correlated, but the tax value was used because it was considered to better reflect the value or importance of this ES across municipalities.

\section{Forest recreation (\% of municipal land covered by forest)}

Forest recreation was assessed using forest cover as an indicator. Forest cover was estimated from land cover maps (BDTQ 2005), joined to a layer of municipal boundaries. The areas of all forest fragments were calculated for each municipality in ArcGIS, and resulting values were outputted into a spreadsheet and added to obtain the total forest area per municipality. This value was divided by the area of the municipality. 


\section{Above-ground carbon sequestration $\left(\mathrm{kgC}\right.$ per $\left.\mathrm{km}^{2}\right)$}

Above-ground carbon sequestration values were calculated from MODIS satellite data representing net primary productivity values (LPDAAC 2001). MOD17 produces gross primary production of vegetation every day, and sums to net primary production at 8-day intervals. The product is computed with daily MODIS landcover, FPAR/LAI and global GMAO surface meteorology at $1 \mathrm{~km}$ for the global vegetated land surface. These variables provide the initial calculation for growing season and carbon cycle analysis, and are used for agriculture, range and forest production estimates.

Two tiles of 2001 data were order from NASA to cover the area of land within the Richelieu and Yamaska watersheds for every 8-day period in 2001. The files were converted to file formats compatible with IDRISI and then 'windowed' to extract the relevant study area. All pixels classified as water or urban (32761 and 32766) were reclassified as 0 . Missing data, presumably caused by cloud cover, was a problem during the months of June and July (classified as 32767), and thus we calculated 'summer' and 'non-summer' totals separately. June and July maps where many pixels were assigned the value of 32767 (n=11) were reclassified to correct for missing values. This was done by taking the average value of NPP for each pixel over the weeks in June and July, only counting the values that were not 32767 . This average value was then multiplied by 11 to find the summer total NPP for those missing 11 8-day periods. Nearest neighbour reclassification was not appropriate in this instance as the missing data pixels were aggregated together in large areas.

The total non-summer NPP was calculated by adding up all the values for each pixel over the year. The total non-summer NPP was added to the total summer NPP to get total NPP values for 2001 at a $1 \mathrm{X} 1 \mathrm{~km}$ resolution. This map was resampled for municipalities using 'zonal' statistics in ArcGIS to obtain an average NPP value per municipality.

Crop yields were calculated for each municipality using the 2001 agricultural census (Statistics Canada 2001d). The amount of carbon present in the portion of cultures that is removed from fields was calculated using average values of $\mathrm{C}$ per crop plant published for Quebec crops (ISQ 2007), multiplied by the percentage of each crop that is typically removed from the field (Whalen et al. 2003). Final amount of $C$ that were removed from fields per municipality were subtracted from the NPP totals per municipality to get the final value of carbon sequestration.

\section{Phosphorus retention in soil (\%)}

Soil samples were taken by the provincial government on every farm in the province, between 1995 and 2001 (MAPAQ 2001). A total of 22,984 soil samples 
were taken within the two study watersheds. Average values for soil retention of phosphorus for each municipality were available via a government online database (MAPAQ 2001). These values only represent the phosphorus saturation values on agricultural land and not across all land covers.

The retention of phosphorus in the soil is indicated by the phosphorus saturation index, which measures the degree to which soil phosphorus (P) sorption sites have been filled (Kleinman and Sharpley 2002). For Quebec soils of the type found in these two watersheds, values above $12 \%$ phosphorus saturation are considered to be at high risk for run-off into waterways (Beauchemin and Simard 2000).

\section{Organic matter in soil (\%)}

Soil samples were taken by the provincial government on every farm in the province, between 1995 and 2001 (MAPAQ 2001). A total of 22,984 soil samples were taken within the two study watersheds. Average values for organic matter in soil for each municipality were available via a government online database (MAPAQ 2001). These values only represent the organic matter in soil on agricultural land, and not across all land covers. Organic matter in soil is widely thought to have a critical level of $3.4 \%$, below which the productive capacity of agriculture is compromised by a deterioration in soil physical properties and the impairment of soil nutrient cycling mechanisms (Loveland and Webb 2003).

\section{SMALLER SCALES $\left(1 \mathrm{~km}^{2}, 9 \mathrm{~km}^{2}\right)$}

Ecosystem services were calculated in the same manner for the $1 \mathrm{~km}^{2}$ and $9 \mathrm{~km}^{2}$ spatial scales. Grids were constructed in ArcGIS at these spatial grains to sample the data.

\section{Crops (\% of land dedicated to crop production)}

Crop production was estimated from land cover maps (BDTQ 2005) joined to the grid layers at both spatial grains. The areas of all croplands were calculated for each grid cell in ArcGIS, and resulting values were outputted into a spreadsheet and added to obtain the total cropland area per grid cell. Land under crop was chosen as an indicator because crop yield values were less comparable across the two watersheds due to differences in crop plants. Land under cultivation is an indicator of how important agriculture is to each municipality, in terms of how much land in total is dedicated to this economic activity.

\section{Pork (number of pork farms)}

Pork production data were taken from unpublished GIS maps created by the Centre de la Nature Mont Saint-Hilaire from data collected from the 15 relevant 
municipalities. Pork production facilities were mapped in point data form and resampled using the grids of both spatial grains.

\section{Maple syrup ( $\%$ of land covered by sugar maple stands)}

Maple syrup production was estimated from unpublished land cover maps produced by the Centre de la Nature Mont Saint-Hilaire joined to the grid layers at both spatial grains. The areas of all sugar maple (Acer saccharum) stands were calculated for each grid cell in ArcGIS, and resulting values were outputted into a spreadsheet and added to obtain the total area per grid cell covered by maple stands. This service was estimated in this way because agricultural census data on number of maple syrup taps or exploited maple stands were not available at small scales.

\section{Deer hunting (number of deer killed)}

Hunting data was obtained from database called The Guide to Hunting and Fishing in Quebec, developed by a private mapping company (SoftMap 2001). Data from 1999 was used that identifies the location of every deer killed that year. Hunters are required to mark on a map the location where they shot the deer when they register the dead deer at their local tagging station. In ArcGIS, the number of points where deer were killed was calculated for each grid cell.

\section{Tourist attractions (number of tourist attractions)}

The number of tourist attractions per municipality was estimated using a provincial government database (MTQ 2007b). A document accompanying the database lists the criteria used to determine whether a site is included in the tourism database (criteria include factors such as having infrastructure aimed at hosting tourists, being registered with the provincial regulating body, conforming with local and provincial laws and regulations, etc, as well as more specific criteria pertaining to types of tourist sites) (MTQ 2007a). The addresses of the tourist attractions were used to locate them on a GIS map in order to sample the number of points within each grid cell.

\section{Nature appreciation (number of reported sightings of rare species)}

This data was collected by the MDDEP (Ministry for Sustainable Development, Environment and Parks) and the MRNF (Ministry for Natural Resources and Fauna) from 1988 to 2007 and was available as a shapefile for the region requested (CDPNQ 2007). The number of points where rare species of flora and fauna were observed was calculated in ArcGIS for each grid cell. This data includes observations of endangered or threatened floral and faunal species within the two study 
watersheds (in accordance with classifications under CITES). Observations are not considered to represent an accurate portrait of rare and endangered species in the region, but rather a reflection of areas that have been frequented by scientists and nature enthusiasts and where these species were observed.

\section{Forest recreation (\% of municipal land covered by forest)}

Forest recreation was assessed using forest cover as an indicator. Forest cover was estimated from land cover maps (BDTQ 2005), joined to the grid layers at both spatial grains. The areas of all forest fragments were calculated for each grid cell in ArcGIS, and resulting values were outputted into a spreadsheet and added to obtain the total forest area per grid cell. 
Appendix 2. Evidence associated with assigning scale of ecosystem service processes.

Table A.2.1: Identifying scales of ecosystem service production

\begin{tabular}{|c|c|c|c|c|}
\hline $\begin{array}{l}\text { Ecosystem } \\
\text { service }\end{array}$ & $\begin{array}{l}\text { Factors contributing to the } \\
\text { production of service }\end{array}$ & Scale & References & $\begin{array}{l}\text { Scale of } \\
\text { production }\end{array}$ \\
\hline \multirow[t]{5}{*}{$\begin{array}{l}\text { Crop } \\
\text { production }\end{array}$} & Human engineering & Site & $\begin{array}{l}\text { (MA 2003, 2005a, b, Tscharntke et al. 2005, Vermaat et } \\
\text { al. 2005) }\end{array}$ & \multirow[t]{5}{*}{ Site } \\
\hline & Regulating services in soil & Site & $\begin{array}{l}\text { (Cumming and Spiesman 2006, MA 2003, 2005a, b, } \\
\text { O'Neill et al. 1989, Tallis and Polasky 2009) }\end{array}$ & \\
\hline & Wind regulation & Site & (MA 2005a, b) & \\
\hline & Pest control & $\begin{array}{l}\text { Site to } \\
\text { local }\end{array}$ & $\begin{array}{l}\text { (Cumming and Spiesman 2006, MA 2005a, b, Tallis and } \\
\text { Polasky 2009) }\end{array}$ & \\
\hline & Erosion control & Site & $\begin{array}{l}\text { (Cumming and Spiesman 2006, Cumming et al. 2006, } \\
\text { Daily 1997, MA 2003, 2005a, b) }\end{array}$ & \\
\hline \multirow[t]{2}{*}{$\begin{array}{l}\text { Pork } \\
\text { production }\end{array}$} & Crop production & Site & $\begin{array}{l}\text { (Cumming et al. 2006, Daily 1997, MA 2005a, b, } \\
\text { Tscharntke et al. 2005, Vermaat et al. 2005) }\end{array}$ & \multirow[t]{2}{*}{ Site } \\
\hline & $\begin{array}{l}\text { Factors underlying crop } \\
\text { production }\end{array}$ & $\begin{array}{l}\text { Site to } \\
\text { local }\end{array}$ & (MA 2003, 2005a, b, Vermaat et al. 2005) & \\
\hline \multirow[t]{3}{*}{$\begin{array}{l}\text { Drinking } \\
\text { water }\end{array}$} & Regulating services in soil & Site & $\begin{array}{l}\text { (Cumming and Spiesman 2006, Lant et al. 2005, MA } \\
2003,2005 a, b \text { ) }\end{array}$ & \multirow[t]{3}{*}{$\begin{array}{l}\text { Regional } \\
\text { (watershed) }\end{array}$} \\
\hline & Erosion control & Site & (Conroy et al. 2003, Lant et al. 2005, MA 2005a, b) & \\
\hline & $\begin{array}{l}\text { Watershed dynamics, including } \\
\text { landscape patterns (e.g. riparian } \\
\text { zones) }\end{array}$ & Watershed & $\begin{array}{l}\text { (Brauman et al. 2007, Conroy et al. 2003, Lant et al. } \\
\text { 2005, MA 2005a, b, O'Neill et al. 1989, Tscharntke et al. } \\
\text { 2005, van Jaarsveld et al. 2005) }\end{array}$ & \\
\hline $\begin{array}{l}\text { Maple syrup } \\
\text { production }\end{array}$ & Pest regulation & $\begin{array}{l}\text { Site to } \\
\text { local }\end{array}$ & (Cumming et al. 2006, Daily 1997, MA 2005a, b) & Site \\
\hline \multirow[t]{3}{*}{ Deer hunting } & $\begin{array}{l}\text { Matrix of land covers (including } \\
\text { connectivity of forest, proximity } \\
\text { of agricultural land) }\end{array}$ & $\begin{array}{l}\text { Local to } \\
\text { regional }\end{array}$ & $\begin{array}{l}\text { (Cumming and Spiesman 2006, Lant et al. 2005, MA } \\
\text { 2003, 2005a, b, Tscharntke et al. 2005) }\end{array}$ & \multirow[t]{3}{*}{$\begin{array}{l}\text { Local } \\
\text { (landscape) } \\
\text { to regional }\end{array}$} \\
\hline & Forest habitat & Local & (MA 2005a, b) & \\
\hline & Food species & Local & (MA 2005a, b, Vermaat et al. 2005) & \\
\hline Nature & Landscape beauty & Local & (MA 2003, 2005a, b, Vermaat et al. 2005) & Local \\
\hline
\end{tabular}




\begin{tabular}{|c|c|c|c|c|}
\hline \multirow[t]{2}{*}{ appreciation } & $\begin{array}{l}\text { Matrix of land covers (including } \\
\text { connectivity) }\end{array}$ & $\begin{array}{l}\text { Local to } \\
\text { regional }\end{array}$ & $\begin{array}{l}\text { (Cumming and Spiesman 2006, Lant et al. 2005, MA } \\
\text { 2003, 2005a, b, Tscharntke et al. 2005) }\end{array}$ & \multirow[t]{2}{*}{$\begin{array}{l}\text { (landscape) } \\
\text { to regional }\end{array}$} \\
\hline & Rare and interesting species & $\begin{array}{l}\text { Local to } \\
\text { regional }\end{array}$ & (MA 2005a, b, Reid et al. 2006, Vermaat et al. 2005) & \\
\hline \multirow{3}{*}{ Tourism } & Landscape beauty & Local & (MA 2003, 2005a, b, Reid et al. 2006) & \multirow{3}{*}{$\begin{array}{l}\text { Local } \\
\text { (landscape) }\end{array}$} \\
\hline & $\begin{array}{l}\text { Unique landscape features (e.g. } \\
\text { mountains) }\end{array}$ & Local & (MA 2005a, b, Vermaat et al. 2005) & \\
\hline & Specific terrain for recreation & Local & (MA 2005a, b, Reid et al. 2006) & \\
\hline \multirow{3}{*}{$\begin{array}{l}\text { Summer } \\
\text { cottages }\end{array}$} & Landscape beauty & Local & (MA 2003, 2005a, b) & \multirow{3}{*}{$\begin{array}{l}\text { Local } \\
\text { (landscape) }\end{array}$} \\
\hline & $\begin{array}{l}\text { Landscape features (e.g. lakes, } \\
\text { forest, mountains) }\end{array}$ & Local & (MA 2005a, b, Vermaat et al. 2005) & \\
\hline & Amenity services & Local & (MA 2005a, b) & \\
\hline \multirow{2}{*}{$\begin{array}{l}\text { Forest } \\
\text { recreation }\end{array}$} & Landscape beauty & Local & (MA 2003, 2005a, b, Reid et al. 2006) & \multirow{2}{*}{$\begin{array}{l}\text { Local } \\
\text { (landscape) }\end{array}$} \\
\hline & Topography & Local & (MA 2005a, b, Vermaat et al. 2005) & \\
\hline \multirow[t]{2}{*}{$\begin{array}{l}\text { Carbon } \\
\text { sequestration }\end{array}$} & Regulating ecosystem services & Site & $\begin{array}{l}\text { (Cumming and Spiesman 2006, Gibson et al. 2000, Lant } \\
\text { et al. 2005, MA 2003, 2005a, b) }\end{array}$ & \multirow[t]{2}{*}{ Site } \\
\hline & Human engineering & Site & $\begin{array}{l}\text { (Cumming and Spiesman 2006, Lant et al. 2005, MA } \\
\text { 2003, 2005a, b) }\end{array}$ & \\
\hline \multirow{2}{*}{$\begin{array}{l}\text { Soil retention } \\
\text { of } \\
\text { phosphorus }\end{array}$} & Regulating ecosystem services & Site & $\begin{array}{l}\text { (Conroy et al. 2003, Cumming and Spiesman 2006, } \\
\text { Lant et al. 2005, MA 2003, 2005a, b, O'Neill et al. 1989) }\end{array}$ & \multirow[t]{2}{*}{ Site } \\
\hline & Human engineering & Site & $(\mathrm{MA} 2003,2005 \mathrm{a}, \mathrm{b})$ & \\
\hline \multirow{2}{*}{$\begin{array}{l}\text { Soil organic } \\
\text { matter }\end{array}$} & Regulating ecosystem services & Site & (MA 2003, 2005a, b) & \multirow[t]{2}{*}{ Site } \\
\hline & Human engineering & Site & (MA 2003, 2005a, b) & \\
\hline
\end{tabular}


Appendix 3. Identifying scales of ecosystem service benefit distribution

Table A.3.1

\begin{tabular}{|c|c|c|c|}
\hline $\begin{array}{l}\text { Ecosystem } \\
\text { service }\end{array}$ & $\begin{array}{l}\text { Scale of } \\
\text { benefits }\end{array}$ & Rationale & $\begin{array}{l}\text { Additional scales of } \\
\text { demand }\end{array}$ \\
\hline $\begin{array}{l}\text { Crop } \\
\text { production }\end{array}$ & Site & $\begin{array}{l}\text { Farmers are the primary beneficiaries of crop production through harvesting and sale } \\
\text { of crops. Crops are harvested directly from sites (fields). }\end{array}$ & $\begin{array}{l}\text { Regional/global markets, } \\
\text { provincial economy }\end{array}$ \\
\hline $\begin{array}{l}\text { Pork } \\
\text { production }\end{array}$ & Site & $\begin{array}{l}\text { Farmers are the primary beneficiaries of pork production through raising and sale of } \\
\text { pigs. The final product is sold from the site (farm). }\end{array}$ & $\begin{array}{l}\text { Regional/global markets, } \\
\text { provincial economy }\end{array}$ \\
\hline $\begin{array}{l}\text { Drinking } \\
\text { water }\end{array}$ & $\begin{array}{l}\text { Local } \\
\text { (municipal) }\end{array}$ & $\begin{array}{l}\text { Surface water is harvested from local rivers for uptake into water treatment plants } \\
\text { that serve municipalities. Entire municipalities consume water from the same } \\
\text { treatment centre. }\end{array}$ & \\
\hline $\begin{array}{l}\text { Maple syrup } \\
\text { production }\end{array}$ & Site & $\begin{array}{l}\text { Farmers are the primary beneficiaries of maple syrup production through harvesting } \\
\text { and sale of maple syrup. Maple syrup is harvested directly from sites (maple stands). }\end{array}$ & $\begin{array}{l}\text { Regional/global markets, } \\
\text { provincial economy }\end{array}$ \\
\hline Deer hunting & $\begin{array}{l}\text { Site to local } \\
\text { (landscape) }\end{array}$ & $\begin{array}{l}\text { Deer hunting occurs on specific sites or across local landscapes. The hunters are the } \\
\text { primary beneficiaries of deer kills and may stay at one site (a field or forest site) or } \\
\text { move over the landscape using multiple sites and tracking deer. }\end{array}$ & $\begin{array}{l}\text { Regional interest }- \\
\text { hunters from outside of } \\
\text { area }\end{array}$ \\
\hline $\begin{array}{l}\text { Nature } \\
\text { appreciation }\end{array}$ & $\begin{array}{l}\text { Site to local } \\
\text { (landscape) }\end{array}$ & $\begin{array}{l}\text { Observers of rare species visit landscapes to observe nature and are the primary } \\
\text { beneficiaries of nature appreciation. They sometimes appreciate plant or animal } \\
\text { species at a particular site. }\end{array}$ & $\begin{array}{l}\text { Regional interest - } \\
\text { enthusiasts from } \\
\text { metropolitan areas }\end{array}$ \\
\hline Tourism & $\begin{array}{l}\text { Site to local } \\
\text { (landscape) }\end{array}$ & $\begin{array}{l}\text { Tourists and tourism operators are the primary beneficiaries of tourism sites and } \\
\text { enjoy this service either at a particular site or in a local area as they move across the } \\
\text { landscape. }\end{array}$ & $\begin{array}{l}\text { Regional and Provincial } \\
\text { tourists }\end{array}$ \\
\hline $\begin{array}{l}\text { Summer } \\
\text { cottages }\end{array}$ & $\begin{array}{l}\text { Site to local } \\
\text { (landscape) }\end{array}$ & $\begin{array}{l}\text { Cottage dwellers are the primary beneficiaries of summer cottages and enjoy this } \\
\text { service on site (cottage land) or at the level of the local landscape if their } \\
\text { surrounding area and land use patterns are important for this enjoyment. }\end{array}$ & $\begin{array}{l}\text { Regional property } \\
\text { owners }\end{array}$ \\
\hline $\begin{array}{l}\text { Forest } \\
\text { recreation }\end{array}$ & $\begin{array}{l}\text { Site to local } \\
\text { (landscape) }\end{array}$ & $\begin{array}{l}\text { Recreators of different types are the primary beneficiaries of forest recreation } \\
\text { services and generally move across the forest landscape to enjoy these services. In } \\
\text { some cases (e.g. mushroom picking) they may utilize specific sites to enjoy a } \\
\text { service. }\end{array}$ & $\begin{array}{l}\text { Regional interest in } \\
\text { recreation }\end{array}$ \\
\hline Carbon & Global & Global populations are the primary beneficiaries of carbon sequestration as it & \\
\hline
\end{tabular}




\begin{tabular}{|c|c|c|c|}
\hline sequestration & & $\begin{array}{l}\text { contributes to climate regulation. Global carbon markets exist to capture the } \\
\text { consumption of this service. }\end{array}$ & \\
\hline $\begin{array}{l}\text { Soil retention } \\
\text { of phosphorus }\end{array}$ & $\begin{array}{l}\text { Site and } \\
\text { regional } \\
\text { (watershed) }\end{array}$ & $\begin{array}{l}\text { Farmers are the primary beneficiaries of this service on sites where the service is } \\
\text { produced as they benefit from phosphorus being retained in their fields to maintain } \\
\text { soil fertility and contribute to crop production. Farmers are given incentives to } \\
\text { maintain this service at the site level. Watershed populations are also primary } \\
\text { beneficiaries of this service as it contributes to maintaining water quality at this } \\
\text { higher scale. }\end{array}$ & $\begin{array}{l}\text { Regional, provincial and } \\
\text { national interest in } \\
\text { maintaining water } \\
\text { quality }\end{array}$ \\
\hline $\begin{array}{l}\text { Soil organic } \\
\text { matter }\end{array}$ & Site & $\begin{array}{l}\text { Farmers are the primary beneficiaries of soil organic matter as it contributes directly } \\
\text { to crop production in their fields and makes their land more or less valuable. }\end{array}$ & \\
\hline
\end{tabular}


Appendix 4. Details of how scales of ecosystem service management were identified

\section{Table A.4.1: Management of landscape engineering}

\begin{tabular}{|c|c|c|c|c|}
\hline \multirow{3}{*}{$\begin{array}{l}\text { Ecosystem } \\
\text { service }\end{array}$} & \multicolumn{4}{|c|}{ Landscape engineering } \\
\hline & \multicolumn{2}{|l|}{ Actions } & \multicolumn{2}{|l|}{ Rules } \\
\hline & Managers* & Scale & Managers* & Scale \\
\hline \multirow[t]{5}{*}{$\begin{array}{l}\text { Crop } \\
\text { production }\end{array}$} & \multirow[t]{5}{*}{$\begin{array}{l}\text { Farmers prepare and clear land } \\
\text { for crop production }\end{array}$} & \multirow[t]{5}{*}{ Site } & $\begin{array}{l}\text { Municipalities share responsibility with province } \\
\text { for regulating land use }\end{array}$ & $\begin{array}{l}\text { Local } \\
\text { (municipality) }\end{array}$ \\
\hline & & & $\begin{array}{l}\text { MRC Vallee-du-Richelieu manages land use and } \\
\text { agricultural water drainage }\end{array}$ & Regional \\
\hline & & & $\begin{array}{l}\text { MAPAQ regulates agricultural infrastructure, } \\
\text { sanitation \& hygiene }\end{array}$ & Regional \\
\hline & & & $\begin{array}{l}\text { CREM works with municipalities to develop } \\
\text { Agenda } 21 \text { on sustainable development }\end{array}$ & $\begin{array}{l}\text { Local } \\
\text { (municipality) }\end{array}$ \\
\hline & & & $\begin{array}{l}\text { CPTAQ regulates activities in agriculture zoned } \\
\text { lands }\end{array}$ & Regional \\
\hline \multirow[t]{5}{*}{$\begin{array}{l}\text { Pork } \\
\text { production }\end{array}$} & \multirow{5}{*}{$\begin{array}{l}\text { Farmers build infrastructure, } \\
\text { grow crops for feed, distribute } \\
\text { manure on land }\end{array}$} & \multirow[t]{5}{*}{ Site } & $\begin{array}{l}\text { Municipalities share responsibility with province } \\
\text { for regulating land use }\end{array}$ & $\begin{array}{l}\text { Local } \\
\text { (municipality) }\end{array}$ \\
\hline & & & MRC Vallee-du Richelieu manages land use & Regional \\
\hline & & & $\begin{array}{l}\text { MAPAQ regulates agricultural infrastructure, } \\
\text { sanitation \& hygiene, animal health }\end{array}$ & Regional \\
\hline & & & $\begin{array}{l}\text { BAPE provides recommendations to } \\
\text { municipalities, province on pork production } \\
\text { management }\end{array}$ & Regional \\
\hline & & & $\begin{array}{l}\text { Citizen groups lobby for regulation, location of } \\
\text { pork production facilities }\end{array}$ & $\begin{array}{l}\text { Local } \\
\text { (municipality) }\end{array}$ \\
\hline $\begin{array}{l}\text { Drinking } \\
\text { water }\end{array}$ & $\begin{array}{l}\text { Farmers install drainage, clear } \\
\text { land near water, alter hydrology }\end{array}$ & Site & $\begin{array}{l}\text { Municipalities have complete jurisdiction over } \\
\text { management of drinking water and restoration of } \\
\text { surface water quality }\end{array}$ & $\begin{array}{l}\text { Local } \\
\text { (municipality) }\end{array}$ \\
\hline
\end{tabular}




\begin{tabular}{|c|c|c|c|c|}
\hline & $\begin{array}{l}\text { Municipalities install } \\
\text { infrastructure beside rivers }\end{array}$ & $\begin{array}{l}\text { Local } \\
\text { (municipality) }\end{array}$ & $\begin{array}{l}\text { Provincial government (MAPAQ) establishes } \\
\text { policies on water }\end{array}$ & Regional \\
\hline & \multirow{2}{*}{$\begin{array}{l}\text { Province, CREM, Nature } \\
\text { Conservancy, Nature-Action clean } \\
\text { and stabilize shorelines, clean } \\
\text { riverbeds }\end{array}$} & \multirow[t]{2}{*}{$\begin{array}{l}\text { Site to local } \\
\text { (landscape) }\end{array}$} & $\begin{array}{l}\text { Watershed organization (COVABAR) advocates } \\
\text { water management }\end{array}$ & $\begin{array}{l}\text { Regional } \\
\text { (watershed) }\end{array}$ \\
\hline & & & $\begin{array}{l}\text { CREM works with municipalities to develop } \\
\text { Agenda } 21 \text { on sustainable development }\end{array}$ & $\begin{array}{l}\text { Local } \\
\text { (municipality) }\end{array}$ \\
\hline \multirow[t]{2}{*}{$\begin{array}{l}\text { Maple syrup } \\
\text { production }\end{array}$} & \multirow[t]{2}{*}{$\begin{array}{l}\text { Farmers clear brush, tap maple } \\
\text { trees }\end{array}$} & \multirow[t]{2}{*}{ Site } & $\begin{array}{l}\text { Municipalities share responsibility with province } \\
\text { for regulating land use }\end{array}$ & $\begin{array}{l}\text { Local } \\
\text { (municipality) }\end{array}$ \\
\hline & & & MAPAQ regulates agricultural infrastructure & Regional \\
\hline \multicolumn{5}{|l|}{ Deer hunting } \\
\hline \multirow[t]{4}{*}{$\begin{array}{l}\text { Nature } \\
\text { appreciation }\end{array}$} & \multirow{4}{*}{$\begin{array}{l}\text { For some species and habitats, } \\
\text { restoration projects serve to } \\
\text { enhance this service, but this is } \\
\text { rare to date }\end{array}$} & \multirow[t]{4}{*}{ Local } & Municipalities regulate land cover change in parks & $\begin{array}{l}\text { Local } \\
\text { (municipality) }\end{array}$ \\
\hline & & & $\begin{array}{l}\text { MDDEP, MRNF regulate land cover change in } \\
\text { provincial protected areas }\end{array}$ & Regional \\
\hline & & & $\begin{array}{l}\text { CREM works with municipalities to develop } \\
\text { Agenda } 21\end{array}$ & $\begin{array}{l}\text { Local } \\
\text { (municipality) }\end{array}$ \\
\hline & & & $\begin{array}{l}\text { MRNF regulates 'Loi sur la conservation et la } \\
\text { mise en valeur de la faune' which outlines } \\
\text { what is permitted in nature areas }\end{array}$ & Regional \\
\hline \multirow[t]{2}{*}{ Tourism } & $\begin{array}{l}\text { Tourism operators build } \\
\text { infrastructure, enhance related } \\
\text { services such as landscape } \\
\text { beauty, floral biodiversity, alter } \\
\text { land cover and topography }\end{array}$ & Site & $\begin{array}{l}\text { Municipalities have partial control over regulation } \\
\text { of tourism operations }\end{array}$ & $\begin{array}{l}\text { Local } \\
\text { (municipality) }\end{array}$ \\
\hline & $\begin{array}{l}\text { CREM and Nature Conservancy } \\
\text { clean and stabilize shorelines }\end{array}$ & Site to local & $\begin{array}{l}\text { Tourisme Quebec shares regulation of tourism } \\
\text { operations }\end{array}$ & Regional \\
\hline $\begin{array}{l}\text { Summer } \\
\text { cottages }\end{array}$ & $\begin{array}{l}\text { Land owners clear land, enhance } \\
\text { related services such as } \\
\text { biodiversity, shade }\end{array}$ & Site & Municipalities for regulate residential land use & $\begin{array}{l}\text { Local } \\
\text { (municipality) }\end{array}$ \\
\hline Forest & Land owners clear underbrush in & Site & CREM works with municipalities to develop & Local \\
\hline
\end{tabular}




\begin{tabular}{|c|c|c|c|c|}
\hline \multirow[t]{4}{*}{ recreation } & some cases, create trails or paths & & $\begin{array}{l}\text { Agenda } 21 \text { on sustainable development, including } \\
\text { forest management }\end{array}$ & (municipality) \\
\hline & $\begin{array}{l}\text { Municipalities, provincial } \\
\text { government and NGOs (CNMSH) } \\
\text { build and maintain trails in } \\
\text { protected areas }\end{array}$ & $\begin{array}{l}\text { Local } \\
\text { (landscape) }\end{array}$ & \multirow[t]{3}{*}{$\begin{array}{l}\text { MRNF, CNMSH develops management plans for } \\
\text { pests and fires in forested areas, works with } \\
\text { private forest owners on land management issues }\end{array}$} & \multirow[t]{3}{*}{$\begin{array}{l}\text { Local to } \\
\text { regional }\end{array}$} \\
\hline & $\begin{array}{l}\text { MRNF manages pests, fires in } \\
\text { forested areas }\end{array}$ & Regional & & \\
\hline & $\begin{array}{l}\text { Nature-Action restores natural } \\
\text { lands }\end{array}$ & $\begin{array}{l}\text { Local } \\
\text { (municipal) }\end{array}$ & & \\
\hline \multicolumn{5}{|l|}{$\begin{array}{l}\text { Carbon } \\
\text { sequestratio } \\
n\end{array}$} \\
\hline $\begin{array}{l}\text { Soil } \\
\text { retention of } \\
\text { phosphorus }\end{array}$ & $\begin{array}{l}\text { Land owners (farmers and other } \\
\text { residents) input fertilizers into } \\
\text { soil }\end{array}$ & Site & $\begin{array}{l}\text { Provincial government regulates phosphorus } \\
\text { inputs to soil }\end{array}$ & Regional \\
\hline $\begin{array}{l}\text { Soil organic } \\
\text { matter }\end{array}$ & $\begin{array}{l}\text { Land owners (farmers and other } \\
\text { residents) input organic material } \\
\text { into soil }\end{array}$ & Site & & \\
\hline
\end{tabular}

Table A.4.2: Management of access to ecosystem services

\begin{tabular}{|l|l|l||l|l|}
\hline \multirow{2}{*}{ Ecosystem service } & \multicolumn{3}{|c|}{ Access to service } \\
\cline { 2 - 4 } & \multicolumn{1}{|c|}{ Managers } & \multicolumn{2}{c|}{ Scale } & \multicolumn{2}{c|}{ Managers } & \multicolumn{1}{|c|}{ Scale } \\
\cline { 2 - 5 } & $\begin{array}{l}\text { Farmers protect private } \\
\text { Crop production }\end{array}$ & Site & $\begin{array}{l}\text { CPTAQ regulates activities in agriculture zoned } \\
\text { lands }\end{array}$ & Regional \\
\hline Pork production & Farmers protect private & Site & MAPAQ awards permits for pork farming & Regional \\
\hline
\end{tabular}




\begin{tabular}{|c|c|c|c|c|}
\hline & property & & & \\
\hline Drinking water & $\begin{array}{l}\text { Municipalities and MRC } \\
\text { Vallee-du-Richelieu build } \\
\text { and maintain water } \\
\text { distribution infrastructure }\end{array}$ & $\begin{array}{l}\text { Local } \\
\text { (municipality) }\end{array}$ & $\begin{array}{l}\text { Municipalities have complete jurisdiction over } \\
\text { access to drinking water }\end{array}$ & $\begin{array}{l}\text { Local } \\
\text { (municipality) }\end{array}$ \\
\hline $\begin{array}{l}\text { Maple syrup } \\
\text { production }\end{array}$ & $\begin{array}{l}\text { Farmers protect private } \\
\text { property }\end{array}$ & Site & $\begin{array}{l}\text { CPTAQ regulates activities in agriculture zoned } \\
\text { lands }\end{array}$ & Regional \\
\hline Deer hunting & $\begin{array}{l}\text { Land owners protect } \\
\text { private property, negotiate } \\
\text { with hunting organizations } \\
\text { for access to land }\end{array}$ & Site & $\begin{array}{l}\text { MRNF distributes hunting permits, runs licensing } \\
\text { tests, registers kills, develops management plans } \\
\text { including establishing deer hunting quotas, } \\
\text { seasons }\end{array}$ & Regional \\
\hline \multirow[t]{2}{*}{$\begin{array}{l}\text { Nature } \\
\text { appreciation }\end{array}$} & $\begin{array}{l}\text { Land owners protect } \\
\text { private property }\end{array}$ & Site & $\begin{array}{l}\text { CREM works with municipalities to regulate } \\
\text { access to wetlands }\end{array}$ & $\begin{array}{l}\text { Local } \\
\text { (municipality) }\end{array}$ \\
\hline & $\begin{array}{l}\text { CREM, CNMSH, } \\
\text { municipalities, MDDEP } \\
\text { build trails, facilitate } \\
\text { access to public wild areas }\end{array}$ & Site to local & $\begin{array}{l}\text { CPTAQ regulates activities in agriculture zoned } \\
\text { lands }\end{array}$ & Regional \\
\hline \multirow[t]{2}{*}{ Tourism } & \multirow{2}{*}{$\begin{array}{l}\text { Bonjour Quebec, } \\
\text { municipalities promote } \\
\text { tourism sites to enhance } \\
\text { access }\end{array}$} & \multirow[t]{2}{*}{$\begin{array}{l}\text { Local to } \\
\text { regional }\end{array}$} & $\begin{array}{l}\text { CPTAQ regulates activities in agriculture zoned } \\
\text { lands }\end{array}$ & Regional \\
\hline & & & $\begin{array}{l}\text { Bonjour Quebec regulates tourism promotion, } \\
\text { develops criteria for categorization and } \\
\text { promotion of tourism sites }\end{array}$ & Regional \\
\hline Summer cottages & $\begin{array}{l}\text { Land owners protect } \\
\text { private property }\end{array}$ & Site & & \\
\hline \multirow[t]{2}{*}{ Forest recreation } & $\begin{array}{l}\text { Land owners protect } \\
\text { private property }\end{array}$ & Site & $\begin{array}{l}\text { CREM works with municipalities to regulate } \\
\text { access to forested areas }\end{array}$ & $\begin{array}{l}\text { Local } \\
\text { (municipality) }\end{array}$ \\
\hline & $\begin{array}{l}\text { CREM, municipalities, } \\
\text { MDDEP build trails, } \\
\text { facilitate access to public } \\
\text { wild areas }\end{array}$ & Site to local & $\begin{array}{l}\text { CPTAQ regulates activities in agriculture zoned } \\
\text { lands }\end{array}$ & Regional \\
\hline Carbon & & & & \\
\hline
\end{tabular}




\begin{tabular}{|l|l|l||l|}
\hline sequestration & & & \\
\hline $\begin{array}{l}\text { Soil retention of } \\
\text { phosphorus }\end{array}$ & & $\begin{array}{l}\text { Provincial laws now regulate phosphorus inputs } \\
\text { on agricultural land, which theoretically allows } \\
\text { people within watersheds access to this } \\
\text { ecosystem service. }\end{array}$ & \begin{tabular}{l} 
Regional \\
\hline Soil organic matter
\end{tabular} \\
\hline
\end{tabular}

*16 important ecosystem service managers in case study area of Mont Saint-Hilaire Man \& Biosphere Reserve

MDDEP: Québec Ministère du Développement durable, de l'Environnement et des Parcs

MAPAQ: Québec Ministère de l'Agriculture, des Pêcheries et de l'Alimentation

COVABAR: Comité de Concertation et de Valorisation de la Rivière Richelieu

MRNF: Québec Ministère des Ressources naturelles et de la Faune

CREM: Conseil régional de l'environnement de la Montérégie

CPTAQ: Québec Commission de Protection du Territoire Agricole

MAMROT: Québec Ministère des Affaires Municipales, des Régions et de l'Occupation du territoire

BAPE: Québec Bureau d'Audiences Publiques sur l'Environnement

Nature Conservancy Québec: Non-Governmental Organization focusing on conservation

Nature-Action Québec: Non-Governmental Organization focusing on conservation

CNMSH: Centre de la Nature Mont Saint-Hilaire:

Municipalities: Saint-Antoine-sur-Richelieu, Saint-Denis-sur-Richelieu, Saint-Marc-sur-Richelieu, Saint-Charles-sur-Richelieu,

Saint-Mathieu-de-Beloeil, Beloeil, Sainte-Marie-Madeleine, Mont-Saint-Hilaire, McMasterville, Otterburn Park,

Saint-Basile-le-Grand, Saint-Jean-Baptiste, Saint-Mathias-sur-Richelieu, Chambly, Carignan

MRC Vallee-du-Richelieu: Municipalité Régionale de Comté - supralocal government combining municipalities in a region

Farmers: Occupying the majority of the land territory in the region

Other landowners: Occupying mostly urban and peri-urban areas in the region

Tourism operators: D 
Appendix 5. Summary scales of ecosystem service production, consumption and management

Table A.5.1

\begin{tabular}{|c|c|c|c|c|c|c|c|}
\hline \multirow{3}{*}{$\begin{array}{l}\text { Ecosystem } \\
\text { service }\end{array}$} & \multirow{3}{*}{$\begin{array}{c}\text { Scale of } \\
\text { production }\end{array}$} & \multirow{3}{*}{$\begin{array}{c}\text { Primary scale } \\
\text { of } \\
\text { consumption }\end{array}$} & \multirow{3}{*}{$\begin{array}{c}\text { Additional scales of } \\
\text { demand }\end{array}$} & \multicolumn{4}{|c|}{ Scales of management } \\
\hline & & & & \multicolumn{2}{|c|}{ Engineering } & \multicolumn{2}{|c|}{ Access } \\
\hline & & & & Actions & Rules & Actions & Rules \\
\hline $\begin{array}{l}\text { Crop } \\
\text { production }\end{array}$ & Site & Site & $\begin{array}{l}\text { Regional/global markets, } \\
\text { provincial economy }\end{array}$ & Site & $\begin{array}{l}\text { Local to } \\
\text { regional }\end{array}$ & Site & Regional \\
\hline $\begin{array}{l}\text { Pork } \\
\text { production }\end{array}$ & Site & Site & $\begin{array}{l}\text { Regional/global markets, } \\
\text { provincial economy }\end{array}$ & Site & $\begin{array}{l}\text { Local to } \\
\text { regional }\end{array}$ & Site & Regional \\
\hline $\begin{array}{l}\text { Drinking } \\
\text { water }\end{array}$ & $\begin{array}{l}\text { Regional } \\
\text { (watershed) }\end{array}$ & $\begin{array}{l}\text { Local } \\
\text { (municipal) }\end{array}$ & none & $\begin{array}{l}\text { Site to } \\
\text { local }\end{array}$ & $\begin{array}{l}\text { Local to } \\
\text { regional }\end{array}$ & Local & Local \\
\hline $\begin{array}{l}\text { Maple syrup } \\
\text { production }\end{array}$ & Site & Site & $\begin{array}{l}\text { Regional/global markets, } \\
\text { provincial economy }\end{array}$ & Site & $\begin{array}{l}\text { Local to } \\
\text { regional }\end{array}$ & Site & Regional \\
\hline Deer hunting & $\begin{array}{l}\text { Local to } \\
\text { Regional }\end{array}$ & $\begin{array}{l}\text { Site to local } \\
\text { (landscape) }\end{array}$ & $\begin{array}{l}\text { Regional interest - hunters } \\
\text { from outside of area }\end{array}$ & none & None & Site & Regional \\
\hline $\begin{array}{l}\text { Nature } \\
\text { appreciation }\end{array}$ & $\begin{array}{l}\text { Local to } \\
\text { regional }\end{array}$ & $\begin{array}{l}\text { Site to local } \\
\text { (landscape) }\end{array}$ & $\begin{array}{l}\text { Regional interest - } \\
\text { enthusiasts from } \\
\text { metropolitan areas }\end{array}$ & none & $\begin{array}{l}\text { Local to } \\
\text { regional }\end{array}$ & $\begin{array}{l}\text { Site to } \\
\text { local }\end{array}$ & $\begin{array}{l}\text { Local to } \\
\text { regional }\end{array}$ \\
\hline Tourism & $\begin{array}{l}\text { Local } \\
\text { (landscape) }\end{array}$ & $\begin{array}{l}\text { Site to local } \\
\text { (landscape) }\end{array}$ & $\begin{array}{l}\text { Regional and Provincial } \\
\text { tourists }\end{array}$ & $\begin{array}{l}\text { Site to } \\
\text { local }\end{array}$ & $\begin{array}{l}\text { Local to } \\
\text { regional }\end{array}$ & $\begin{array}{l}\text { Local to } \\
\text { regional }\end{array}$ & Regional \\
\hline $\begin{array}{l}\text { Summer } \\
\text { cottages }\end{array}$ & $\begin{array}{l}\text { Local } \\
\text { (landscape) }\end{array}$ & $\begin{array}{l}\text { Site to local } \\
\text { (landscape) }\end{array}$ & Regional property owners & Site & Local & Site & None \\
\hline $\begin{array}{l}\text { Forest } \\
\text { recreation }\end{array}$ & $\begin{array}{l}\text { Local } \\
\text { (landscape) }\end{array}$ & $\begin{array}{l}\text { Site to local } \\
\text { (landscape) }\end{array}$ & $\begin{array}{l}\text { Regional interest in } \\
\text { recreation }\end{array}$ & $\begin{array}{l}\text { Site to } \\
\text { local }\end{array}$ & $\begin{array}{l}\text { Local to } \\
\text { regional }\end{array}$ & $\begin{array}{l}\text { Site to } \\
\text { local }\end{array}$ & $\begin{array}{l}\text { Local to } \\
\text { Regional }\end{array}$ \\
\hline $\begin{array}{l}\text { Carbon } \\
\text { sequestration }\end{array}$ & Site & Global & none & none & none & none & None \\
\hline $\begin{array}{l}\text { Soil retention } \\
\text { of phosphorus }\end{array}$ & Site & $\begin{array}{l}\text { Site and } \\
\text { regional } \\
\text { (watershed) }\end{array}$ & $\begin{array}{l}\text { Regional interest in } \\
\text { maintaining water quality }\end{array}$ & Site & Regional & none & None \\
\hline $\begin{array}{l}\text { Soil organic } \\
\text { matter }\end{array}$ & Site & Site & none & Site & none & None & None \\
\hline
\end{tabular}



Appendix 6. Results of correlation analyses

Figure A.6.1 Correlations among ecosystem services across three scales. Positive correlations are shown in blue and negative correlations are shown in red, with darker shades signifying stronger correlations.

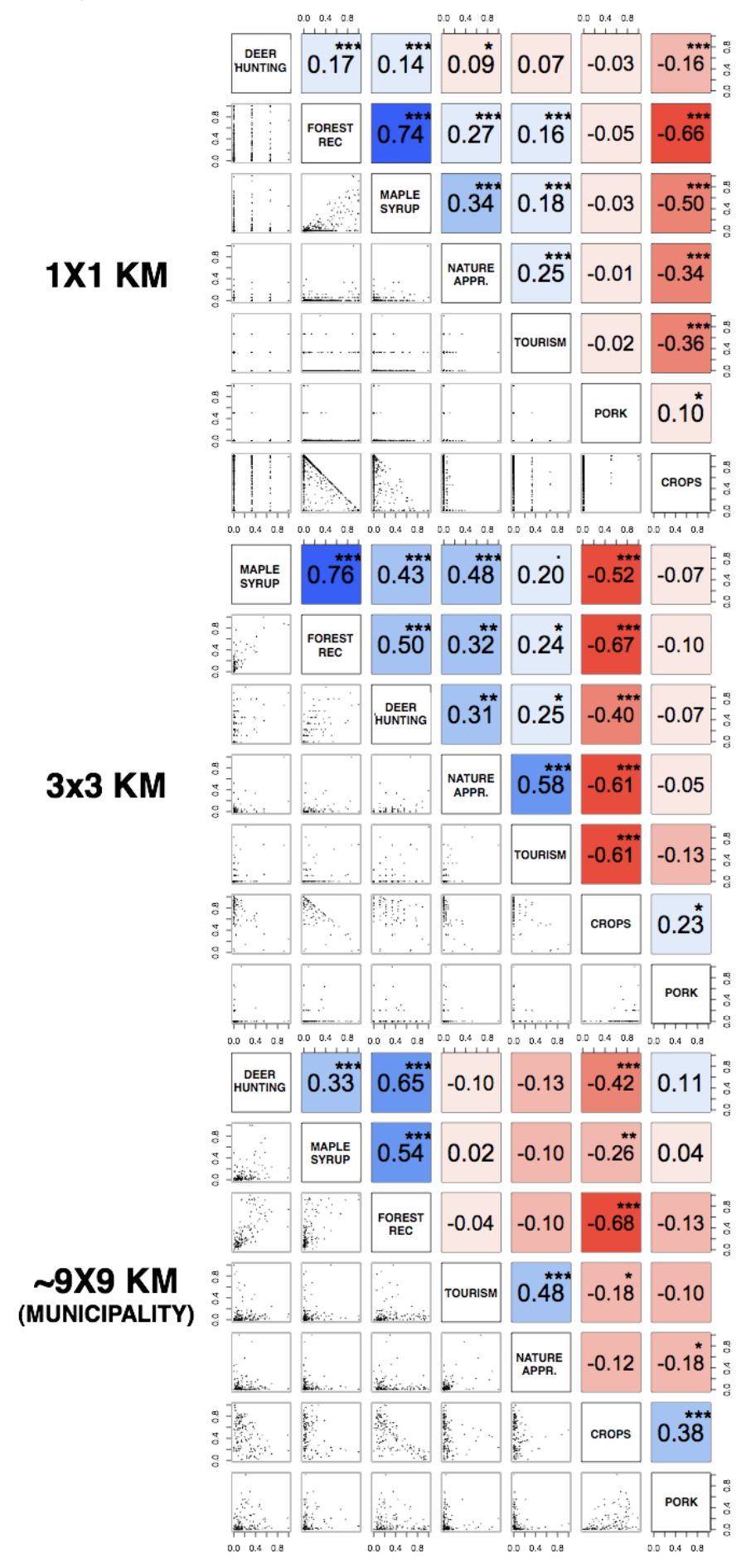


Figure A.6.2 Correlations across municipalities ( $\mathrm{n}=137)$, including all 12 ecosystem services for which there was data at the largest scale.

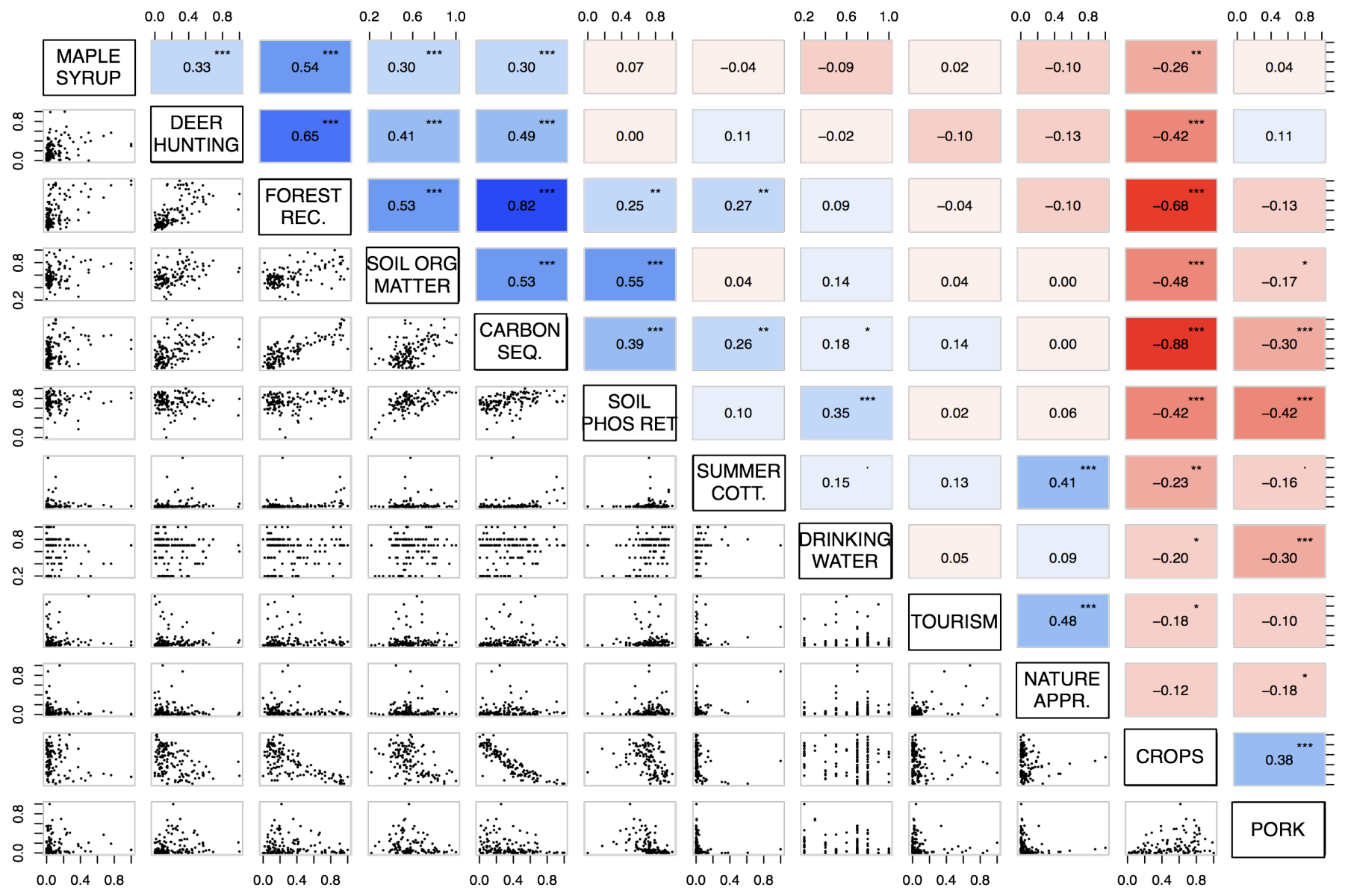

